\title{
Recent Advances in the Chemistry and Therapeutic Evaluation of Naturally Occurring and Synthetic Withanolides
}

\author{
Amandeep Singh ${ }^{1}$, Asif Raza ${ }^{1}$, Shantu Amin ${ }^{1}$, Chendil Damodaran ${ }^{2}$ and Arun K. Sharma ${ }^{1, *(\mathbb{D})}$ \\ 1 Department of Pharmacology, Penn State Cancer Institute, CH72, Penn State College of Medicine, \\ Penn State Milton S. Hershey Medical Center, 500 University Drive, Hershey, PA 17033, USA; \\ asingh8@pennstatehealth.psu.edu (A.S.); mraza@pennstatehealth.psu.edu (A.R.); sga3@psu.edu (S.A.) \\ 2 Department of Pharmaceutical Sciences, Texas AM University, College Station, TX 77842, USA; \\ chendamodar@tamu.edu \\ * Correspondence: asharma1@pennstatehealth.psu.edu or aks14@psu.edu; Tel.: +717-531-4563; \\ Fax: +717-531-0244
}

Citation: Singh, A.; Raza, A.; Amin S.; Damodaran, C.; Sharma, A.K. Recent Advances in the Chemistry and Therapeutic Evaluation of Naturally Occurring and Synthetic Withanolides. Molecules 2022, 27, 886. https://doi.org/10.3390/ molecules 27030886

Academic Editor: Wolfgang Sippl

Received: 21 December 2021

Accepted: 27 January 2022

Published: 28 January 2022

Publisher's Note: MDPI stays neutral with regard to jurisdictional claims in published maps and institutional affiliations.

Copyright: (C) 2022 by the authors. Licensee MDPI, Basel, Switzerland. This article is an open access article distributed under the terms and conditions of the Creative Commons Attribution (CC BY) license (https:// creativecommons.org/licenses/by/ $4.0 /)$.

\begin{abstract}
Natural products are a major source of biologically active compounds that make promising lead molecules for developing efficacious drug-like molecules. Natural withanolides are found in many flora and fauna, including plants, algae, and corals, that traditionally have shown multiple health benefits and are known for their anti-cancer, anti-inflammatory, anti-bacterial, antileishmaniasis, and many other medicinal properties. Structures of these withanolides possess a few reactive sites that can be exploited to design and synthesize more potent and safe analogs. In this review, we discuss the literature evidence related to the medicinal implications, particularly anticancer properties of natural withanolides and their synthetic analogs, and provide perspectives on the translational potential of these promising compounds.
\end{abstract}

Keywords: withanolides; withaferin A; anticancer; anti-inflammatory; anti-bacterial; anti-leishmaniasis

\section{Introduction}

Phytochemicals are a rich resource for small molecule drug discovery and have provided leads for several approved drugs and those entering clinical trials [1]. The development of the first commercial drugs, such as morphine and aspirin, proved the capability of the successful purification and synthesis of drugs from plants [2]. Many of the FDAapproved anti-cancer molecules are natural products or direct synthetic derivatives of natural products, of which plants are the most compelling source [1,3,4]. Although natural products have been extensively used in drug discovery, it is thought that there are still many unexplored plant-based sources used in traditional medicine that could be probed to design and develop new pharmaceuticals in modern medicine [5].

Withanolides belong to a group of naturally occurring C-28 steroid lactones [6]. These compounds are generally highly oxygenated, and these functionalities have led to many structural modifications [7-10]. The current classification of withanolides constitutes 22 types based on their structural differences. Withanolides, isolated primarily from genera belonging to the plant family Solanaceae, have captured interest mainly due to their diverse structural features and significant biological activities against several diseases [11-18]. Withania, a genus of Solanaceae, has been used for over 3000 years as a medicine in Southeast/Southwest Asia in the Ayurvedic system. Ashwagandha (Withania somnifera), Indian Ginseng, is the most popular herb commonly used to improve both physical and mental health $[19,20]$. Traditionally, topical application of the berries and leaves of this plant is used as a remedy for ulcers and tumors [7]. Apart from that, it also showed anti-stress [21,22], anti-inflammatory [23-27], anti-oxidant [24,28-30], and anti-depressant [31,32] properties [33-36]. Withanolides, with 28 carbons of naturally occurring steroids, are the main chemical constituents of the Withania genus [37]. Withaferin A (WA) is one of the most 
active withanolides, and it is mainly responsible for the bioactivity of Ashwagandha [7,10]. WA has shown anti-diabetic, anti-cancer [38-46], and anti-angiogenesis [47,48] effects and has attracted the attention of the scientific world to understand its mechanism(s) of action. This is despite the fact that structurally, the three potential reactive sites susceptible to nucleophilic attack, e.g., the unsaturated A-ring at C3, the epoxide structure at position 5, and C-24 in its E-ring (Figure 1) [7,49], have been demonstrated to bind covalently to cysteine residues of proteins, thereby causing loss of activity of the target protein. WA has been shown to exert its anti-cancer effect through the induction of apoptosis in various human cancer cell lines, including breast, prostate, leukemia, colon, pancreatic, renal, head and neck, and many others. WA has been shown to inhibit pro-survival signaling, such as Notch1, MAPK and NF- $\mathrm{kB}$ activation, and concomitantly induce pro-apoptotic signaling that results in the growth inhibition of many cancer types [50,51].

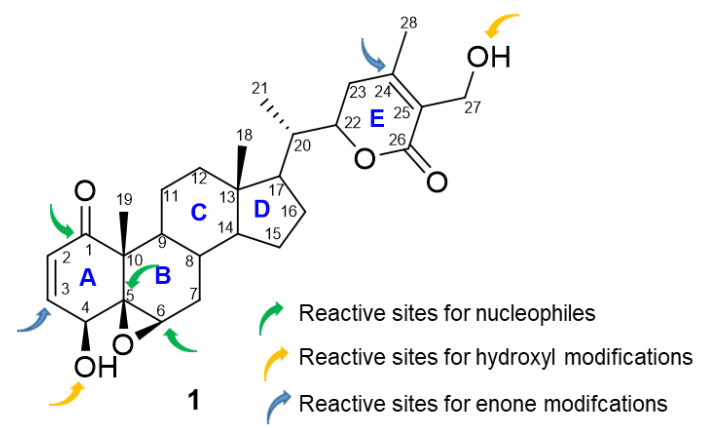

Figure 1. Structure of Withaferin A (WA, 1) and its reactive sites exploited for structural modifications.

This article primarily focuses on the anti-cancer activity of naturally occurring withanolides and their synthetic analogs. Cancer, characterized by the abnormal growth of cells, is the second most fatal disease globally. Several factors, such as tobacco use, over body weight, gene mutation, and hormone and immune conditions, are major causes of the disease [52]. According to WHO, about 14 million new cases are found annually, with 9 million deaths in 2018. Alarmingly by 2030, cancer-related deaths are predicted to increase to about 13.1 million [53]. Although the cause of cancer is related to the unchecked growth of cells, its pathogenesis is extremely complex and involves several interlinked mechanisms. Some of the most studied mechanisms include sustaining proliferative signaling, evading growth suppressors, resisting cell death, enabling replicative immortality, activating invasion and metastasis, inducing angiogenesis, tumor-promoting inflammation, genome instability, and mutation, evading immune destruction, and reprogramming energy metabolism [54,55]. Many anti-cancer agents have been developed, which play an important role in the different steps, such as kinase inhibitors acting on the signal transduction in cells, B-cell lymphoma-2 (Bcl-2) family proteins inhibitors regulating the apoptosis, cell mitosis regulators, epigenetic modifiers, immune regulators, and so on [56-59]. The Food and Drug Administration (FDA) has approved approximately 150 anti-cancer agents, but a complete cure for cancer remains a challenge. Most of the chemotherapies remain unsuccessful due to acquired resistance. Compounds derived from natural products, such as withanolides, as such or after structural optimizations, may provide effective and safer drug candidates with lower systemic toxicity. Thus, having a high therapeutic index could lead to the development of more efficacious anti-cancer drugs.

\section{Withanolides as Anti-Cancer Agents}

This section provides details of the anti-cancer properties of naturally occurring withanolides and their synthetic analogs with a discussion of their structure-activity relationship (SAR) studies. 


\subsection{Natural Withanolides}

Since the identification of the first withanolide, WA (1), isolated from the Indian medicinal plant Withania somnifera in 1965 [58], a growing number of bioactive withanolides with complex and unique structures have been reported [59,60]. Due to their unique structural skeletons, withanolides display diverse biological activities, including anticancer, anti-microbial, anti-inflammatory, and immunoregulatory activities [60]. Therefore, they are regarded as important origins of lead compounds and potential drug candidates and, thus, over the years, have attracted the interests of chemists and biologists [61]. Withanolides mainly occur in the family of Solanaceae, exemplified by the genera of Physalis, Datura, and Withania.

\subsubsection{Physalis}

The genus Physalis has more than 100 species and is widely spread in tropical and temperate regions [61]. Many species of this genus have been used as traditional medicine worldwide. For example, 'Ku-Zhi', a folk medicine of Physalis angulata (P. angulata), was used to treat impaludism, dermatitis, tracheitis, rheumatism, and hepatitis and was also adopted for similar usage in Mexico, Indonesia, Peru, and Brazil. The fruits, leaves, and calyxes of $P$. philadelphica have been used to treat diabetes, fever, cough, amygdalitis, and gastrointestinal disorders [61]. The medicinal properties of Physalis have generated interest in extracting and characterizing compounds that its different species possess and identifying the active withanolides responsible for their medicinal properties.

Jhuang Jin and co-workers isolated withanolides 2-4 (Figure 2), with an unusual carbon structure, from $P$. angulata $\mathrm{L}$ using a bioassay-directed isolation technique [62]. All the three isolated withanolides, Physangulidine A, B, and C, were evaluated for their anti-proliferative activities against prostate cancer cells (DU145) and prostate epithelial cells (RWPE-1). Physangulidine A was found the most effective of the three and showed a $\mathrm{GI}_{50}$ (concentration for $50 \%$ of maximal inhibition of cell proliferation) value of 3.0 and $2.4 \mu \mathrm{M}$ against DU145 and RWPE-1 cells, respectively. Physangulidine B and Physangulidine $C$ displayed $\mathrm{GI}_{50}$ values in the range of $6.0-6.8 \mu \mathrm{M}$ against RWPE- 1 and DU145 cells. Physangulidine A also showed similar cytotoxicity against colon adenocarcinoma (HT-29) and hematopoietic malignant cells (K562) cells, with a $\mathrm{GI}_{50}$ value of $2.73 \mu \mathrm{M}$ against each cell line as compared to 5-fluorouracil (5-FU) with $\mathrm{GI}_{50} 5.92$ and $30.32 \mu \mathrm{M}$, respectively. Notably, Physangulidine A also exhibited relatively lower cytotoxicity against non-malignant $3 \mathrm{~T} 3$ cells with a $\mathrm{GI}_{50}$ value of $4.12 \mu \mathrm{M}$ compared to $5-\mathrm{FU}$ with $\mathrm{GI}_{50} 0.28 \mu \mathrm{M}$.

Ting $\mathrm{Ma}$ and co-workers reported five new biologically active withanolides 5-9 (Figure 2) from the plant P. angulata var [63]. They tested them, using cisplatin as a reference drug, against three different human cancer cell lines: hepatocellular liver carcinoma (HepG2), breast cancer (MCF-7), and osteosarcoma (MG-63). All the compounds displayed $\mathrm{IC}_{50}$ (concentration of a drug that is required for $50 \%$ inhibition of cell viability) values in the range of $0.06-6.73 \mu \mathrm{M}$, which were comparable to the reference drug. The most active compounds (5, 6, and 7), having $\alpha, \beta$-unsaturation in the ring $A$, a $5 \beta, 6 \beta$-epoxy in ring $B$, and a lactone ring in the side chain, indicated the importance of these functional groups in the withanolides structure for anti-cancer activity. Mechanistically, the most potent compound, compound 5 , arrested cells in the $\mathrm{G}_{2} / \mathrm{M}$ phase and activated caspase-dependent apoptotic pathways [63]. In addition, the induction of apoptosis by 5 in MG-63 cells was associated with the generation of reactive oxygen species (ROS) and the activation of extracellular signal-regulated kinases (ERKs) and c-Jun N-terminal kinases (JNKs). These pathways are deregulated in several cancer types and, therefore, 5 may be a promising compound for further development as a cancer therapeutic.

Another set of new withanolides, 10-15 (Figure 2), isolated from P. angulate, were screened against human renal carcinoma cells (786-O, A-498, and ACHN), human prostate cancer cells (C4-2B and 22Rvl), and human melanoma cells (A375-S2) [64]. All the compounds exhibited potent anti-proliferative activities against all the tested cell lines, with $\mathrm{IC}_{50}$ values in the range of $0.18-7.43 \mu \mathrm{M}$. Withanolides with $5 \beta, 6 \beta$-epoxy (10) and $5 \alpha$ - 
$\mathrm{Cl}, 6 \beta-\mathrm{OH}(13, \mathbf{1 4})$ moieties were the most potent against all the tested cancer cell lines. These compounds also showed a substantial inhibitory effect on nitric oxide (NO) production. All the withanolides showed an $\mathrm{IC}_{50}$ value in the range of $1.36-5.56 \mu \mathrm{M}$, which was lower than hydrocortisone $\left(\mathrm{IC}_{50}=58.79 \mu \mathrm{M}\right)$ used as a positive control.
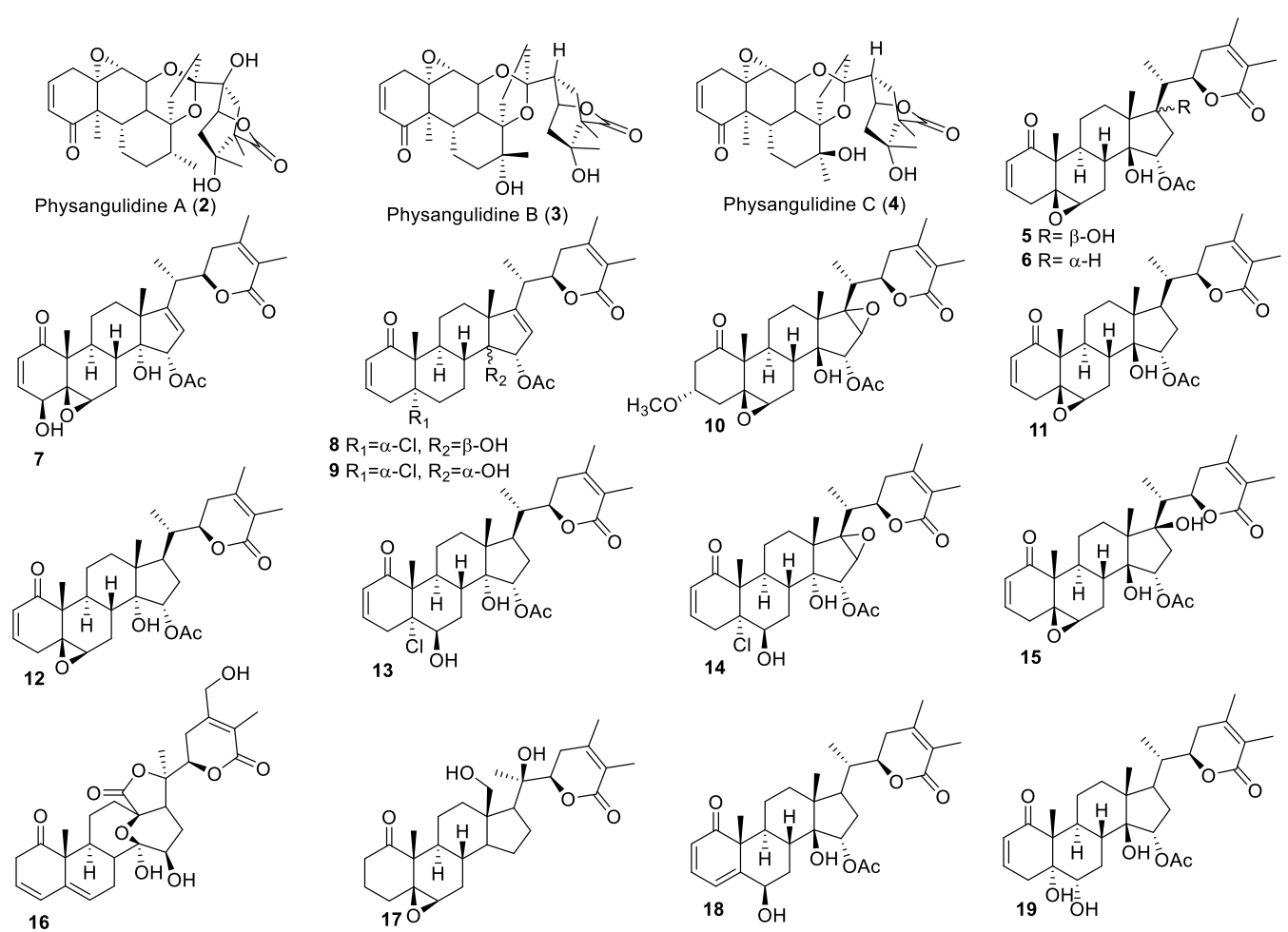

Figure 2. Withanolides isolated from P. angulata.

The DNA barcoding technique was used to identify P. angulate from which two new withanolides, 16 and 17 (Figure 2), were isolated [65] and evaluated for their anti-cancer activity against Menogaril-resistant mouse leukemia (P388 cells), cervical carcinoma (Hela), and adenocarcinomic human alveolar basal epithelial cells (A549) using the cell viability assay. Compound $\mathbf{1 6}$ was found relatively more active than compound $\mathbf{1 7}$ and displayed $\mathrm{IC}_{50}$ values in the range of $8.00-11 \mu \mathrm{M}$. These compounds also induced apoptosis in A549 cellscompound $\mathbf{1 6}$ being nearly twice as potent in inducing apoptosis than compound $\mathbf{1 7}$. Furthermore, a set of two new withanolides, 18 and 19 (Figure 2), was isolated from $P$. angulata using dichloromethane extraction, followed by purification with chromatographic techniques [64]. Evaluation of the anti-cancer property of these compounds against A549, HeLa, and PANC-1 cells revealed compound 18 as the most active compound against A549 and human pancreatic cancer (PANC-1) cell lines, with $\mathrm{IC}_{50}$ values of 13.47 and $20.23 \mu \mathrm{M}$, respectively. Both the compounds were inactive against HeLa cells.

Organic extract of another herb, P. alkekengi L. var franchetii (Mast) Makino, of Solanaceae family [66], found in Asia and Europe, has been shown to exert many medicinal properties, such as anti-inflammatory, anti-oxidant, anti-diabatic, and anti-bacterial [67-69]. Five new withanolides, 20-24 (Figure 3), were isolated from ethanol extract [70] and were tested for their antiproliferative activities against A549 and K562 cell lines. Compound 20 was the most potent among all the newly isolated withanolides and exhibited $\mathrm{IC}_{50}$ values of 4.3 and $2.2 \mu \mathrm{M}$ against A549 and K562 cells, respectively, comparable to Adriamycin with $\mathrm{IC}_{50}$ values of 2.3 and $1.5 \mu \mathrm{M}$, respectively, against the two cell lines. A plausible mechanism, evaluated by Western blot analysis as being responsible for the cytotoxicity of compound 20 against A549 cells, involved the regulation of the PI3K/Akt-mTOR signaling pathway. 
<smiles></smiles>
20

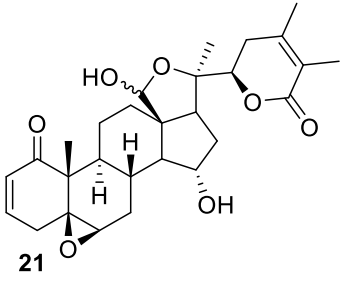
21

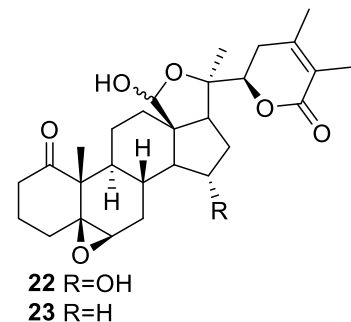

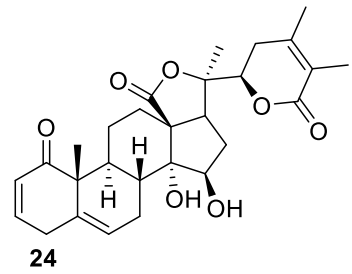

24

Figure 3. Withanolides isolated from P. alkekengi.

Huaping Zhang et al. isolated new withanolides (25-34) (Figure 4) from P. longifolia [71] and evaluated them for their cytotoxicity against head and neck squamous cell carcinoma (HNSCC, JMAR, MDA-1986), melanoma (B16F10 and SKMEL-28), and/or normal fetal fibroblast (MRC-5) cells. All the compounds were active against the tested cell lines, with $\mathrm{IC}_{50}$ values in the range of 0.067-9.3 $\mu \mathrm{M}$. Withanolides (25-29), having a 2-en-1-one in ring A, $5 \beta, 6 \beta$-epoxy in ring $B$, and lactone as a side chain, were the most active compounds and demonstrated the importance of these functionalities. Esterification of the $\mathrm{OH}$ group at the positions C-4, C-19, and C-27 resulted in an enhanced activity profile; acylated compounds 26 and 28a exhibited $\mathrm{IC}_{50}$ values of less than $1 \mu \mathrm{M}$ against all the tested cell lines, which are similar to $\mathrm{WA}\left(\mathrm{IC}_{50}=0.2-4.0 \mu \mathrm{M}\right)$ and less than cisplatin $\left(\mathrm{IC}_{50}=1.0-8.9 \mu \mathrm{M}\right)$, used as a positive control. Withanolide glycosides $\mathbf{3 0}$ and $\mathbf{3 1}$ were less active as compared to WA. The presence of the O-sulfate group in $\mathbf{3 4}$ increased the activity profile compared to its parent compound, 32, against B16F10, JMAR, and MDA-1986 cell lines. Compound 33 was relatively less active, with $\mathrm{IC}_{50}$ values in the range of 3.2-10 $\mu \mathrm{M}$ against all the tested cancer cell lines. Compound $\mathbf{2 6}$ was the most active among all the isolated new withanolides, having an $\mathrm{IC}_{50}$ value of $0.067 \mu \mathrm{M}$ against B16F10.

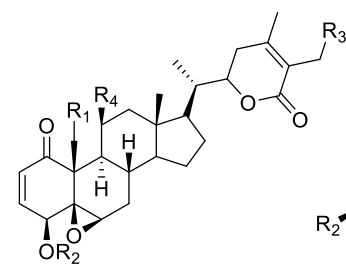

$25 \mathrm{R}_{1}=\mathrm{R}_{3}=\mathrm{OH}, \mathrm{R}_{2}=\mathrm{R}_{4}=\mathrm{H}$ $26 \mathrm{R}_{1}=\mathrm{OH}, \mathrm{R}_{2}=\mathrm{Ac}, \mathrm{R}_{3}=\mathrm{OAc}, \mathrm{R}_{4}=\mathrm{H}$

$27 \mathrm{R}_{1}=\mathrm{R}_{3}=\mathrm{OAc}, \mathrm{R}_{2}=\mathrm{Ac}, \mathrm{R}_{4}=\mathrm{H}$

28a $\mathrm{R}_{1}=\mathrm{OH}, \mathrm{R}_{2}=\mathrm{R}_{3}=\mathrm{R}_{4}=\mathrm{H}$

28b $R_{1}=O A c, R_{2}=R_{3}=R_{4}=H$

28c $R_{1}=O A c, R_{2}=A c, R_{3}=R_{4}=H$

$29 \mathrm{R}_{1}=\mathrm{R}_{4}=\mathrm{R}_{3}=\mathrm{OH}, \mathrm{R}_{2}=\mathrm{H}$

$30 \mathrm{R}_{1}=\mathrm{R}_{2}=\mathrm{R}_{4}=\mathrm{H}, \mathrm{R}_{3}=$ Oglc-rha

$31 R_{1}=R_{2}=R_{4}=H, R_{3}=$ Oglc

$32 \mathrm{R}_{1}=\mathrm{R}_{2}=\mathrm{R}_{4}=\mathrm{H}, \mathrm{R}_{3}=\mathrm{OH}$

Figure 4. Withanolides isolated from P. longifolia.

P. neomexicana Rydb is commonly found in the United States, primarily in Colorado, New Mexico, Arizona, and Texas. The fruit is called the New Mexico ground cherry and has been used as food by the Acoma, Chiricahua, Laguna, Mescalero, San Felipe, and Rio Grande pueblos of New Mexico [72,73]. Cong-Mei Cao et al. isolated four new withanolides, 35-38 (Figure 5), which were evaluated for anti-proliferative activity against MDA-MB231 and MCF-7 breast cancer cell lines using WA ( $\mathrm{IC}_{50} 0.5$ and $1.3 \mu \mathrm{M}$, respectively) and withaloglide $\mathrm{B}$ ( $\mathrm{IC}_{50} 0.2$ and $0.8 \mu \mathrm{M}$, respectively) as references compounds. Among all the four new isolated withanolides, compound $\mathbf{3 6}$ was most active against MDA-MB-231 and MCF-7 cell lines, with $\mathrm{IC}_{50}$ values of 1.7 and $6.3 \mu \mathrm{M}$, respectively [74], being less effective than the two reference compounds. 


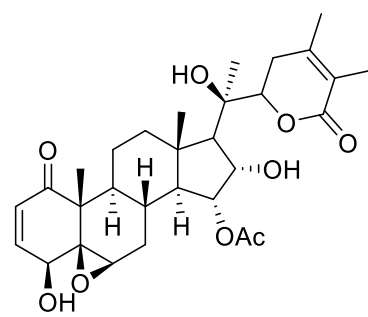

35

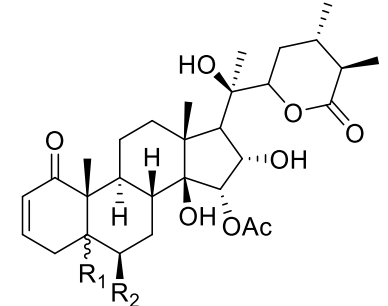

$36 \mathrm{R}_{1} \mathrm{R}_{2}=5 \beta, 6 \beta$-epoxy $37 \mathrm{R}_{1}=\alpha-\mathrm{OH}, \mathrm{R}_{2}=\beta-\mathrm{OH}$

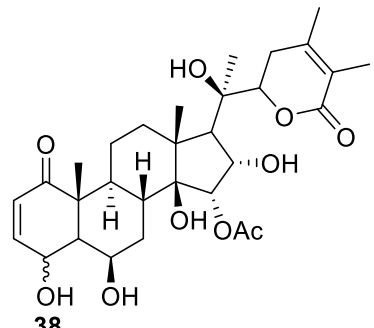

38

Figure 5. Withanolides isolated from P. neomaxicana.

P. crassifolia Benth extract was found most effective of the 18,000 natural product extracts screened in a high throughput gene-expression assay to treat castration-resistant prostate cancer [75]. Withanolides 39-42 (Figure 6) were isolated from P. crassifolia and evaluated against five cancer cell lines using doxorubicin as a standard. These compounds were more potent against androgen-sensitive human prostate adenocarcinoma $\mathrm{LNCaP}\left(\mathrm{IC}_{50} 0.12-3.7 \mu \mathrm{M}\right)$ and PC-3M $(0.43-5.0 \mu \mathrm{M})$ cells compared to the MCF-7 $\left(\mathrm{IC}_{50}>5.0 \mu \mathrm{M}\right)$, non-small-cell lung cancer NCI-H460 $\left(\mathrm{IC}_{50}>5.0 \mu \mathrm{M}\right)$, and CNS glioma SF-268 $\left(\mathrm{IC}_{50}>5.0 \mu \mathrm{M}\right)$ cell lines. The presence of the $\beta-\mathrm{OH}$ group at the $\mathrm{C}-17$ position of the withanolides framework may be responsible for higher potency and selectivity against certain cancer cell lines.

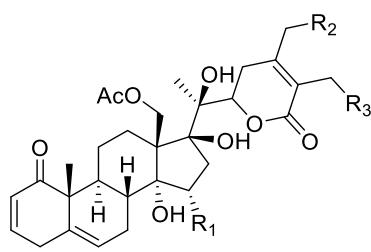

$39 \mathrm{R}_{1}=\mathrm{OH}, \mathrm{R}_{2}=\mathrm{R}_{3}=\mathrm{H}$ $40 \mathrm{R}_{1}=\mathrm{R}_{2}=\mathrm{H}, \mathrm{R}_{3}=\mathrm{OH}$

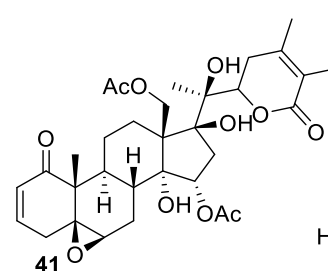

42

Figure 6. Withanolides isolated from P. crassifolia.

P. pubescens L, a rich source of withanolides, is used as a medicine to cure sore throat, cough, urethritis, hematuria, and orchitis [75,76] in China. Guiyang Xia et al. isolated withanolides 43-49 (Figure 7) from P. pubescens L and evaluated them for their anti-proliferative activities against eight human tumor cell lines (C4-2B, 22Rvl, 786-O, A-498, Caki-2, ACHN, A375, and A375-S2) and a human normal hepatic cell line (L02) [77]. Compounds 43 and 44 , with the $4 \beta$-hydroxy-2-en-1-one group in ring $A$ and the $5 \beta, 6 \beta$-epoxy group in ring $\mathrm{B}$, were identified as the most potent against all the tested cancer cell lines, with $\mathrm{IC}_{50}$ values in the range of $0.17-5.30 \mu \mathrm{M}$. Compounds $45-49$, without these functionalities, were inactive, which demonstrated the importance of these functional groups for anticancer activity [77-79]. Furthermore, these active compounds were relatively less cytotoxic to the L02 cell line.
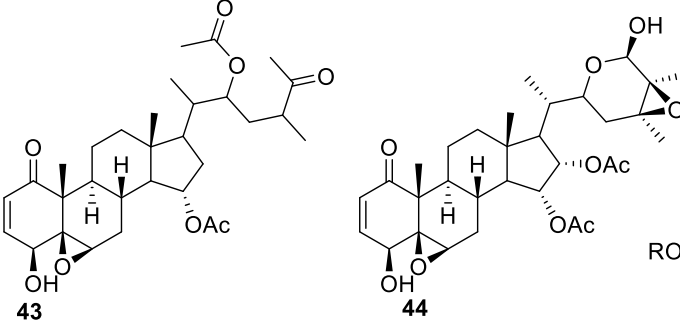

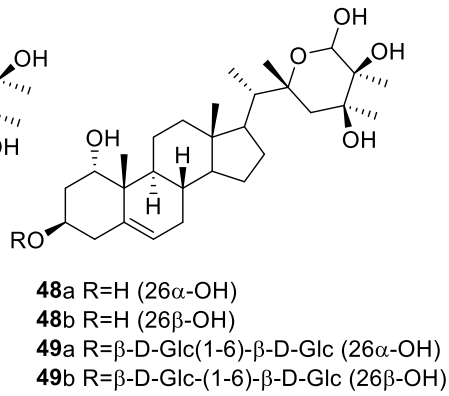

Figure 7. Withanolides isolated from P. pubescens L. 
New withanolides 50-53 (Figure 8) were isolated from P. peruviana by Ya-Ming Xu and co-workers and were tested against a panel of cancer cell lines consisting of LNCaP, 22Rv1, ACHN, M14 (human melanoma), SKMEL-28 (human melanoma), and normal HFF (human foreskin fibroblast) cells [80]. The compounds displayed stronger activities against LNCaP cells $\left(\mathrm{IC}_{50}\right.$ values of $\left.0.12-2 \mu \mathrm{M}\right)$ than other tested cell lines.
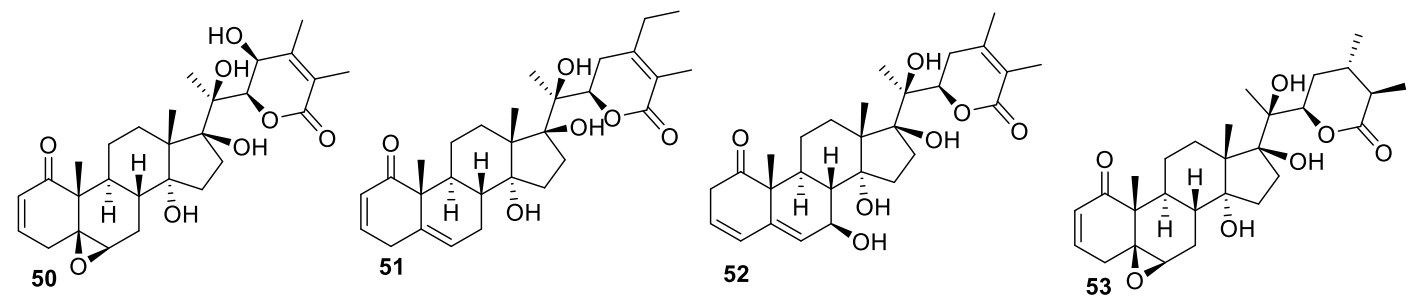

Figure 8. Withanolides isolated from P. peruviana.

\subsubsection{Datura}

The genus Datura, which belongs to the family Solanaceae, contains many species indigenous to the American Southwest, including D. metel, D. inoxia, D. stramonium, and D. wrightii. The genus originates from the Old World and has a worldwide geographical distribution. Traditionally, Datura extracts are used to treat asthma, earache, headache, and tumors and possess several other medicinal properties, including anesthetic, expectorant, demulcent, intoxicant, hypnotic, and sedative effects. Several withanolides have been extracted from this genus and evaluated for their anti-cancer properties.

Dinoxin B (12,21-dihydroxy-1-oxowitha-2,5,24-trienolide-27-O- $\beta$-D-glucopyranoside, 54) (Figure 9), a new type of withanolide, was isolated from $D$. inoxia leaves using bioassayguided fractionation [81]. The extracted compound was evaluated for anti-proliferative activity against 21 different cancer cell lines and three normal cell lines. Compound 54 showed cytotoxicity in the sub-micromolar range against several tested cell lines. This activity was unusual for the withanolides with a glucosylated moiety as compared with other withanolide glycosides [10,82]. To determine the effect of the glucosyl group on the activity, compound 55 was generated from $\mathbf{5 4}$. The $\mathrm{IC}_{50}$ values for compound $\mathbf{5 5}$ against the breast adenocarcinoma viz. T47D, MDA-MB468, and MCF-7 cell lines were 0.99, 0.75, and $0.87 \mu \mathrm{M}$, respectively, which are higher than compound 54 , with $\mathrm{IC}_{50}$ values of $0.22,0.58$, and $0.61 \mu \mathrm{M}$, respectively. In each cell line, compound 54 was relatively more cytotoxic. This is in direct contrast to the bioactivities of other previously reported withanolides, where the presence of a glucose group reduces the cytotoxicity up to $>10$-fold. For example, the reported $\mathrm{IC}_{50}$ values for WA and its glycoside form against MCF-7 cells are 0.6 and $7.9 \mu \mathrm{M}$, respectively [10].

The same group further isolated new withanolides from the aerial part of $D$. wrightii, a rich source of C-21 oxygen-substituted withanolides [83]. The five isolated withanolides, 56-60 (Figure 9), were evaluated for their cytotoxicity against human glioblastoma (U251 and U87), MDA-1986, and normal MRC-5 cells. The compounds showed $\mathrm{IC}_{50}$ values in the range of 0.56 to $3.6 \mu \mathrm{M}$ against the cancer cells and 3.3 to $5.6 \mu \mathrm{M}$ against normal fibroblasts. Although these compounds were less potent compared to WA ( $\left.\mathrm{IC}_{50} 0.19-1.1 \mu \mathrm{M}\right)$, they were found to be more selective towards cancer cells, with average selectivity of between 4- and 7-fold compared to WA, indicating they might have a higher therapeutic index. However, these compounds should be evaluated for their in vivo efficacy/toxicity to determine if the in vitro results translate in animals and if these compounds have a better selectivity profile at efficacious doses than WA. 


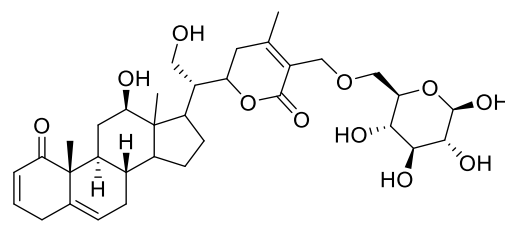
54
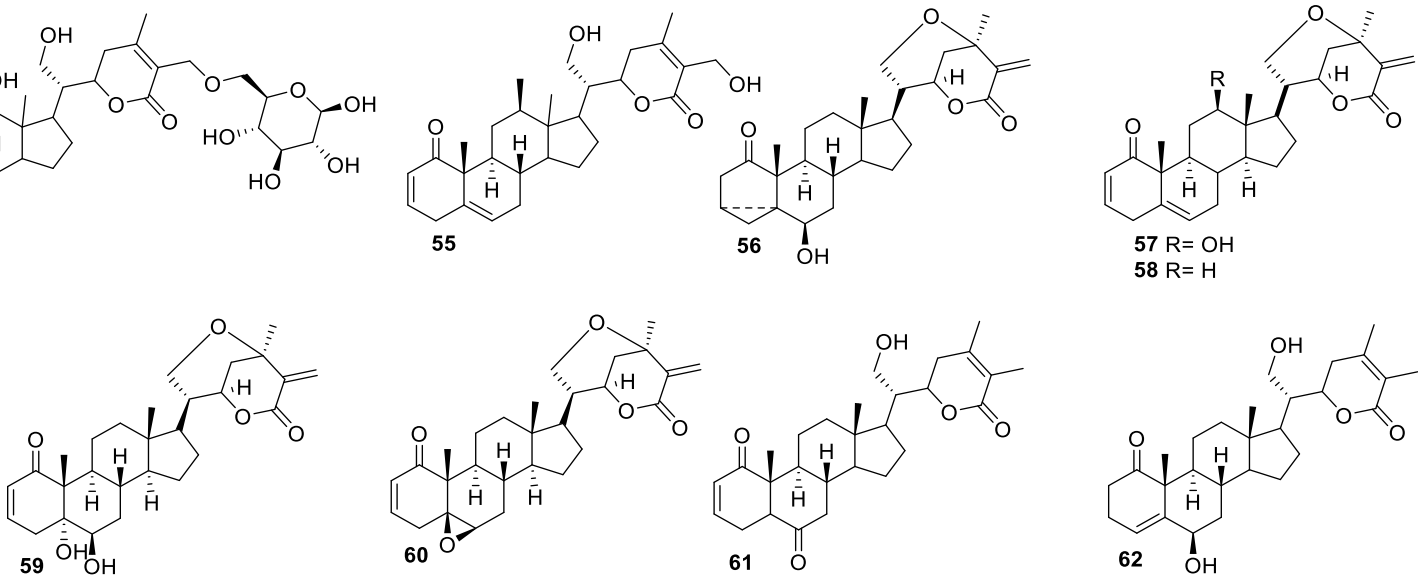
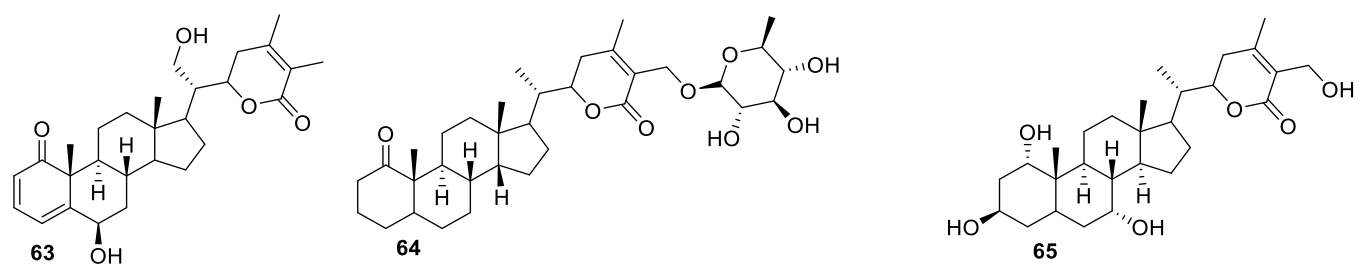

Figure 9. Withanolides isolated from genus Datura.

Daturanolides 61-63 (Figure 9), isolated from the flowers of D. metel L, were also evaluated for their cytotoxicity against five human cancer cell lines (HCT116, U87-MG, NCI-H460, BGC823, and HepG2) [84]. However, none of the compounds showed significant activities against the tested cell lines. Two new withanolides, baimantuoluoside $\mathrm{H}(64)$ and baimantuoluoline K (65) (Figure 9), were isolated and identified from the ethyl acetatesoluble fraction of the ethanol extract of $D$ metel seeds [1]. The structures of the new compounds were assigned based on 1D, 2D NMR and mass spectrometric techniques. All isolated compounds were evaluated for their antiproliferative activity against human gastric adenocarcinoma (SGC-7901), HepG2, and MCF-7 cells using 5-FU as a positive control. These compounds showed moderate activity against the SGC-7901 cancer cell line, with $\mathrm{IC}_{50}$ values of 37.7 and $29.2 \mu \mathrm{g} / \mathrm{mL}$, respectively, while they were inactive against other tested cell lines. Additionally, these compounds showed immunosuppressive effects, with $\mathrm{IC}_{50}$ values of 14.0 and $12.3 \mu \mathrm{g} / \mathrm{mL}$, which is much lower than the standard drug cyclosporine.

\subsubsection{Withania}

Withanolides are the main phytochemical constituents of the Withania genus. Among these, WA has been extensively studied and is shown to be efficacious against several cancers such as glioblastoma, neuroblastoma, multiple myeloma, leukemia, breast, colon, ovarian, and head and neck cancer [85]. Three new withanolides, 66, 67, and 68 (Figure 10), were isolated from Withania coagulans (W. coagulans) [86], which inhibited nitric oxide production in lipopolysaccharide-activated murine macrophage RAW 264.7 cells, with $\mathrm{IC}_{50}$ values in the range of $1.9-29.0 \mu \mathrm{M}$. The most active compounds, 66 and 67 , showed $\mathrm{IC}_{50}$ values of 3.1 and $1.9 \mu \mathrm{M}$. These withanolides have also been shown to inhibit tumor necrosis factor- $\alpha$ (TNF- $\alpha$ )-induced nuclear factor-kappa B (NF- $\mathrm{B}$ ) activation, with $\mathrm{IC}_{50}$ values in the range of $8.8-11.8 \mu \mathrm{M}$. Moreover, the compounds isolated from $W$. coagulans, including certain coagulans, coagulanolides, and coagulins isolated from various plant parts, including roots, leaves, and fruits, have been attributed extensive anti-fungal, anticytotoxic, anti-diabetic, hypolipidemic, neuroprotective, anti-inflammatory, anti-cancerous, anthelmintic, antioxidant, and wound healing activities [87]. 

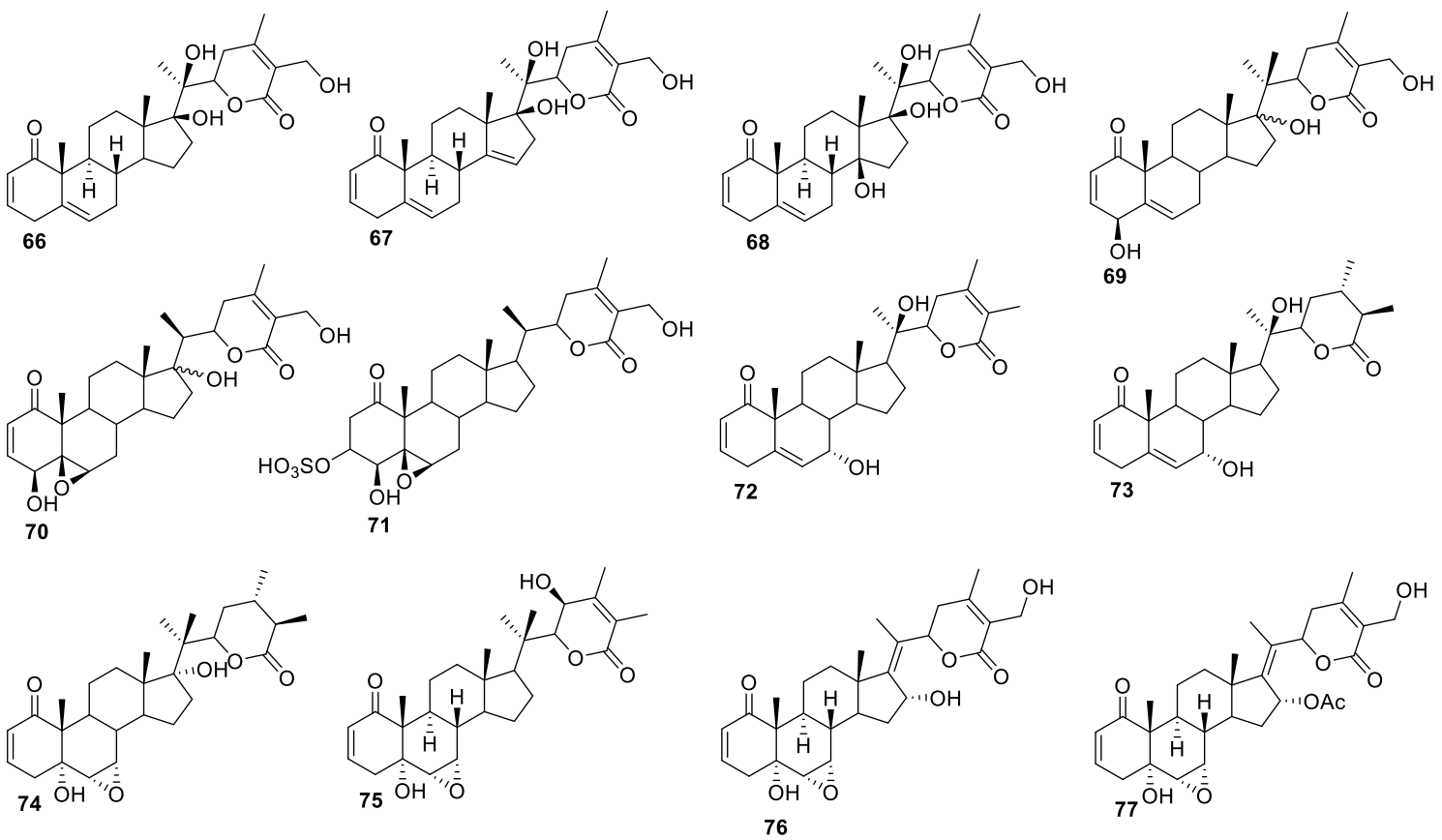

Figure 10. Withanolides isolated from genus Withania.

The anti-cancer potential of $W$. frutescens, which is persistently found in Morocco under the name 'Tirnet' and traditionally used to treat dysentery [88], has been reported against HeLa 229 cell lines [89]. Laila El Bouzidi and group isolated three new withanolides, 69-71 (Figure 10), from Morocco W. frutescens, [90], which were evaluated for their cytotoxicity against HT29 cancer cell lines using 5-FU as a reference compound. Compound $\mathbf{7 1}$ was the most potent, with $\mathrm{IC}_{50}$ value of $1.78 \mu \mathrm{M}$, similar to the standard compound 5-FU. Withanolides 69 and 70 were moderately active, with $\mathrm{IC}_{50}$ values of 13.18 and $25.13 \mu \mathrm{M}$, respectively. The high activity of compound $\mathbf{7 1}$ was likely due to its good aqueous solubility and its capability to convert to WA in the cell culture media [91].

Sil Kim and co-workers isolated six new withanolides, 72-77 (Figure 10), from $W$. somnifera and screened them against four human cancer cell lines (A549, SK-OV-3, SK-MEL2, and HCT-15) [92]. Interestingly, all the tested compounds were inactive against A549 cells $\left(\mathrm{IC}_{50}\right.$ values $\left.>10 \mu \mathrm{M}\right)$. Withanolides 72 and 73 showed some activities against SK-OV-3 cells, with $\mathrm{IC}_{50}$ values of 7.9 and $8.9 \mu \mathrm{M}$, respectively. All the compounds were active against all the remaining cancer cell lines, with $\mathrm{IC}_{50}$ values ranging from 3.4 to $10 \mu \mathrm{M}$.

\subsubsection{Other Natural Sources of Withanolides}

There are several reports of isolation of withanolides from various other natural sources. Ki Hyun Kim and co-workers extracted two new withanolides, named dioscorolide A (78) and dioscorolide B (79) (Figure 11), from Dioscorea japonica Japanese edible yams, the tropical crops that serve as important staple foods in many parts of the world [93]. The structures of these new compounds were assigned using spectroscopic methods, including 1D and 2D NMR techniques, high-resolution mass spectrometry (HRMS), and chemical methods [94]. The isolated compounds were evaluated against four tumor cell lines (A549, SK-OV-3, SK-MEL-2, and HCT15) and a human healthy cell line (HUVEC) using a sulforhodamine B (SRB) assay. Compound 78 was relatively more potent, displaying $\mathrm{IC}_{50}$ values between 6.3-2.9 $\mu \mathrm{M}$ against A549, SK-OV-3, SK-MEL-2, and human colon adenocarcinoma (HCT-15) cell lines compared to 79, with $\mathrm{IC}_{50}$ values in the range of 12.6-25.6 $\mu \mathrm{M}$. Studies showed that the $\alpha, \beta$-unsaturated ketone group in ring A adds to the cytotoxic activity of the withanolides $[95,96]$. The lower cytotoxicity value of $\mathbf{7 9}$ against the SK-OV-3 and SK-MEL-2 cells was attributed to the absence of the $\alpha, \beta$-unsaturated double in the ring $\mathrm{A}$. However, the presence of the acetylthio group at C-3 in 79 relatively increases 
the activity against the A549 and HCT-15 cell lines even though it lacks the 2-en-1-one system in ring $\mathrm{A}$. Both compounds $\mathbf{7 8}$ and $\mathbf{7 9}$ exhibited lower activity against the normal cell line (HUVEC), with $\mathrm{IC}_{50}$ values ranging from 27.1 to $28.8 \mu \mathrm{M}$, suggesting selective toxicity towards tumor cells.
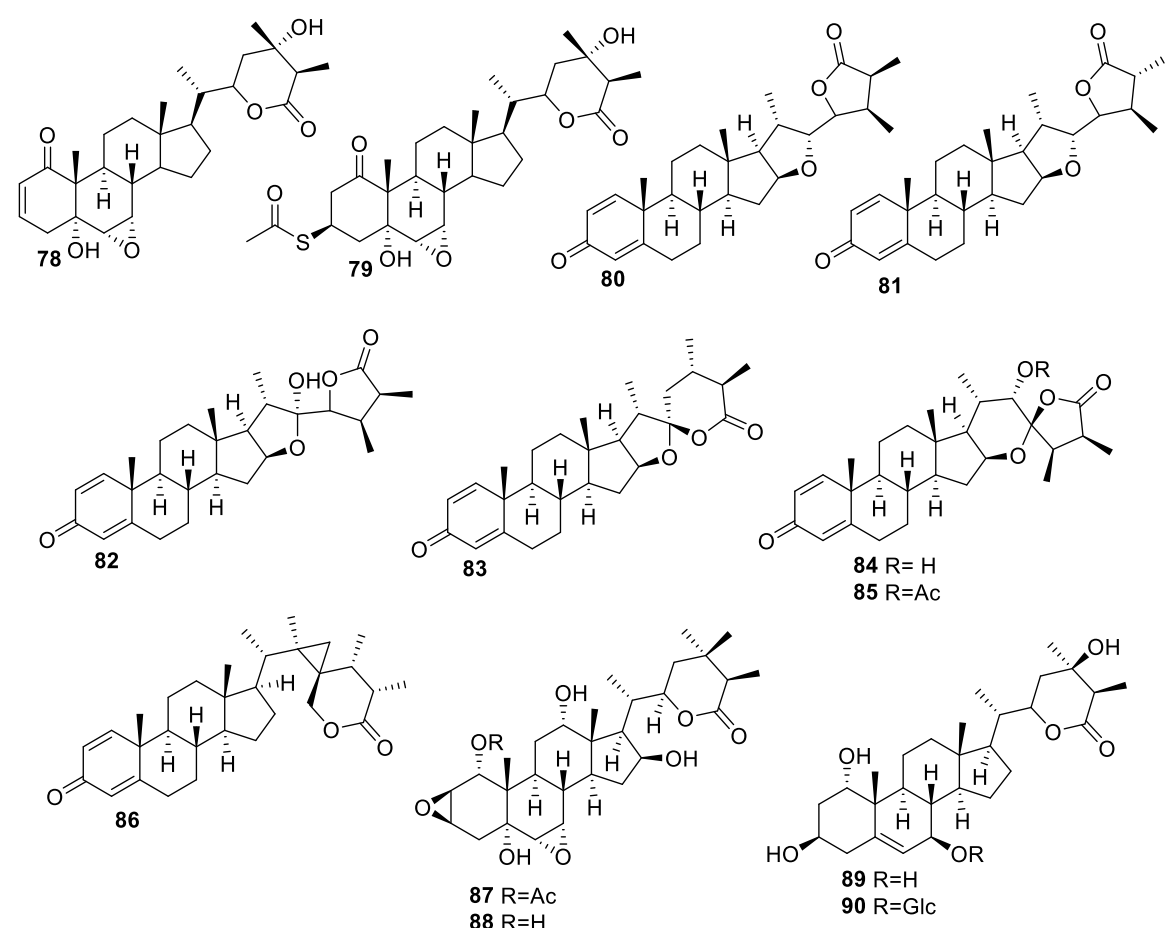

Figure 11. Withanolides isolated from Dioscorea japonica $\mathbf{7 8 - 7 9}$, Sinularia brassica $\mathbf{8 0 - 8 6}$, and Tacca plantaginea 87-90.

Seven novel withanolides, sinubrasolides 80-86 (Figure 11), were isolated from the cultured soft coral Sinularia brassica [97] and were evaluated for their anti-proliferative activities against P388, lymphoid T carcinoma (MOLT 4), K562, and HT-29 cells. Compound 81 was potent against all the cancer cell lines tested, with $\mathrm{ED}_{50}$ values in the range of 4.8 and $9.1 \mu \mathrm{M}$, while 84 showed cytotoxicity toward MOLT-4 and HT-29 cells, with ED 50 values of 9.9 and $7.5 \mu \mathrm{M}$, respectively.

Four new withanolides, including one having a sugar moiety, called plantagiolides, were isolated from Tacca plantaginea. These new withanolides were evaluated for their $\mathrm{TNF} \alpha$-induced NF- $\mathrm{KB}$ transcriptional and cytotoxic activities [98]. The evaluation of the $\mathrm{TNF} \alpha$-induced NF- $\mathrm{kB}$ transcriptional activity of compounds 87-90 (Figure 11) in human embryonic kidney cells (HEK293T) cells using an NF-kB-luciferase assay showed the new compounds to be inactive, with $\mathrm{IC}_{50}$ values greater than $20 \mu \mathrm{M}$.

In order to understand the chemical behavior, Batista and co-workers cultivated Acnistus arborescens and isolated four new withanolides, 91-94 (Figure 12), from their leaves using acetone and ethanol extracts [99]. These withanolides were tested for their cytotoxicity against four human cancer cell lines: acute myeloid leukemia (HL-60), human colorectal carcinoma (HCT-116), SF-268, and PANC-1 cell lines. Withanolide 91 was most active against all the tested cancer cell lines, with $\mathrm{IC}_{50}$ values in the range of $2.2-4.4 \mu \mathrm{M}$. Compound 92 was also active, with $\mathrm{IC}_{50}$ values in the range of 2.2-8.0 $\mu \mathrm{M}$, except for PANC1 cells, against which it was relatively less effective $\left(\mathrm{IC}_{50}\right.$ value $\left.>10 \mu \mathrm{M}\right)$. Compounds 93 and 94 exhibited reduced anti-proliferative potency, probably due to the presence of chlorohydrin in place of the $5 \beta, 6 \beta$-epoxy group (for 93) and the lack of $\mathrm{OH}$ (at C-4) and the $5 \beta, 6 \beta$-epoxy group (for 94) [100]. 


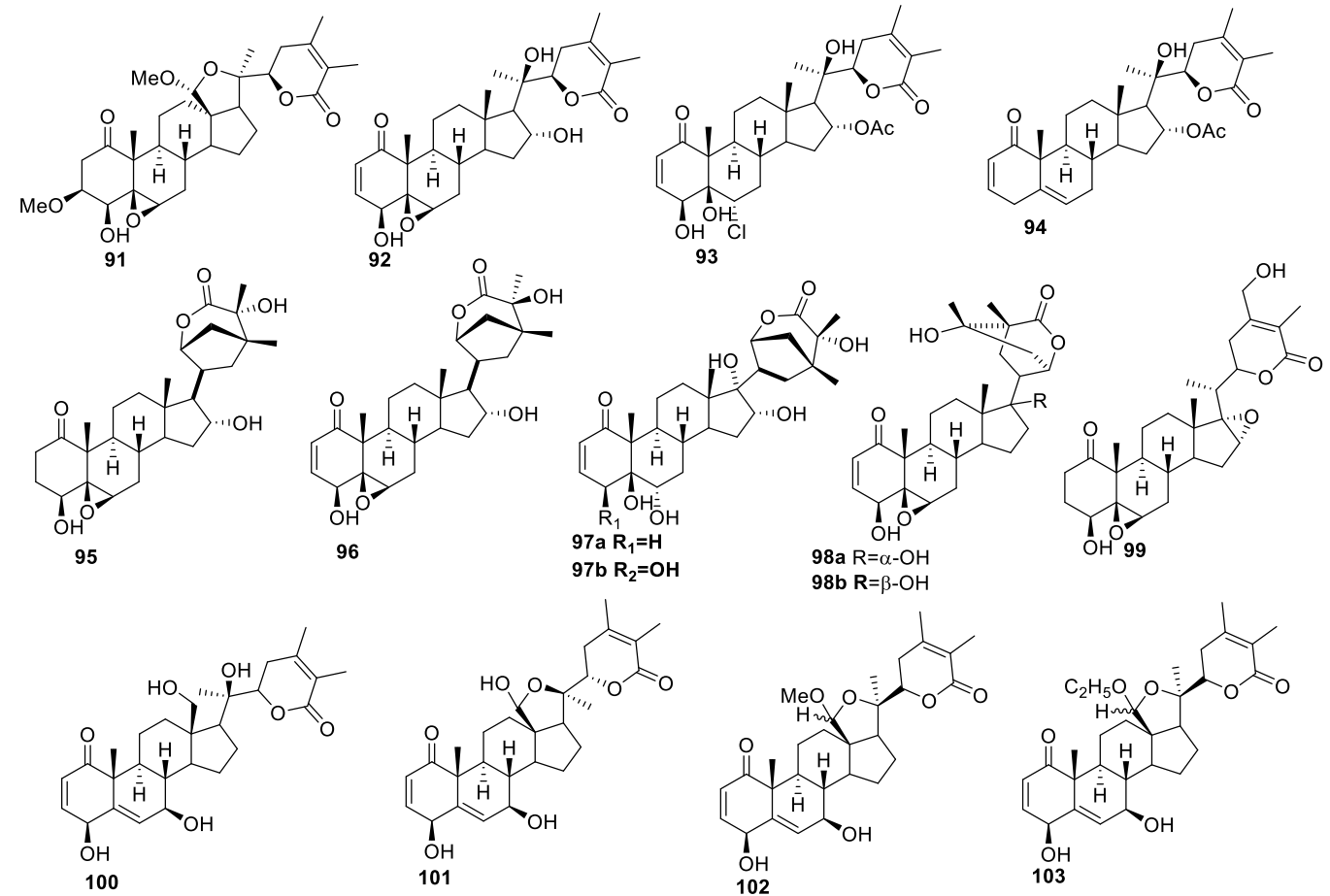

Figure 12. Withanolides isolated from Acnistus arborescens (91-94), Tubocapsicum anomalum (95-99), and Eriolarynx and Deprea (100-103).

Ten new withanolides were isolated from Tubocapsicum anomalum and were screened for anti-proliferative activities against four human tumor cell lines (HCT-116, HepG2, MCF7, and A375) using cisplatin as a positive control [101]. Compounds 95-99 (Figure 12) were the most potent among all the tested withanolides against all the tested cell lines, with $\mathrm{IC}_{50}$ values ranging between $0.24-8.71 \mu \mathrm{M}$. SAR studies revealed that the presence of the $\beta$-hydroxy group at the C-4 position led to an increase in the activity in $97 \mathrm{~b}$, with $\mathrm{IC}_{50}$ values in the range of 3.74-8.10 $\mu \mathrm{M}$ compared to $97 \mathrm{a}$ without the $\mathrm{OH}$ having $\mathrm{IC}_{50}$ values between 4.42-14.03 $\mu \mathrm{M}$ against all the tested cell lines. Compound $\mathbf{9 8 b}$, having $\beta-\mathrm{OH}$ at position C-17, was more active, with $\mathrm{IC}_{50}$ values of $1.14,5.15$, and $3.87 \mu \mathrm{M}$ against Hep-G2, MCF-7, and A375, respectively. On the other hand, compound 98a, with $\alpha-\mathrm{OH}$ at the C-17 position, was less active, with $\mathrm{IC}_{50}$ values of $6.07,14.2$, and $13.1 \mu \mathrm{M}$ against Hep-G2, MCF-7, and A375, respectively.

The genus Eriolarynx Miers is found in Peru, Bolivia, and the hot and humid forest of Sierra de Aconquija in northwestern Argentina between the elevation of 1000 and $2000 \mathrm{~m}$. Withanolides isolated from this species have been studied for various biological activities, including anti-inflammatory activity, the induction of quinone reductase, and cytotoxic activity $[18,102,103]$. Sebastián J. Castro et al. found four new withanolides, 100-103 (Figure 12), from Eriolarynx and Deprea, which were evaluated for their anticancer activities against A549, HBL-100, HeLa, SW1573, T-47D, and colon adenocarcinoma (WiDr) solid tumor cell lines [104]. Compounds 102 and $\mathbf{1 0 3}$ were identified as the most active compounds, displaying $\mathrm{GI}_{50}$ values in the range of $2.4-4.7 \mu \mathrm{M}$ against all the tested cell lines except for WiDr cells. These two compounds were more effective against A549 cell lines, with $\mathrm{GI}_{50}=3.1,2.8 \mu \mathrm{M}$, than the reference drug cisplatin $\left(\mathrm{GI}_{50}=4.9 \mu \mathrm{M}\right)$. The four withanolides were also evaluated for their selectivity against the non-cancer cell line BJ-hTERT. Interestingly, all these new compounds showed 2-10-fold selectivity towards the cancer cell lines. The SAR studies revealed that the presence of an acetal group in compounds 101-103 instead of hydroxyl (100) at the C-18 position increases the activity profiles. Compounds 102 and 103, with the acetal group, were more potent than compound 101 with the hemiacetal group. The difference in activity between these compounds was associated with their higher lipophilicity, with $C \log P$ values for 101-103 being $0.07,0.54$, 
and 0.93 , respectively. In contrast, it is interesting to note that compounds 21-24 (Figure 3), with similar acetal groups, led to a loss of activity compared to 20.

Ya-Ming $\mathrm{Xu}$ and the group screened an 18,000-member library of Sonoran desert plants [105]. They employed 13,500 fractions in a high-throughput ArrayPlate assay to search for small-molecule natural products that affect the expression pattern of a subset of genes that are known to be involved in prostate cancer [106,107]. The most promising extract provided 15 $\alpha$-acetoxyphysachenolide D (104a) [13], 15 $\alpha$-acetoxy-28hydroxyphysachenolide D (104b), 18-acetoxy-17-epi-withanolide K (104c), physachenolide $\mathrm{D}$ (105a), and 15 $\alpha, 18$-diacetoxy-17-epi-withanolide K (105b) (Figure 13) via gene expression assay-guided fractionation. The compounds inhibited the expression of three androgeninduced genes, KLK2, KLK3, and SPDEF, in DHT-activated LNCaP cells, with $\mathrm{IC}_{50}$ values in the range of $0.58-3.58 \mu \mathrm{M}$. The most active compound $104 \mathrm{c}$ showed $\mathrm{IC}_{50}=0.58,0.75$, and $0.77 \mu \mathrm{M}$ for KLK2, KLK3, and SPDEF, respectively. Furthermore, the evaluation of cytotoxicity of compounds 104-105 against glioma (SF-268), prostate (LNCaP and PC-3), breast (MCF-7), and lung (NCI-H460) cancer cell lines were also done. The results demonstrated compound 104c to be the most active and selective towards LNCaP and PC-3 cells, with $\mathrm{IC}_{50}$ values of 70 and $211 \mathrm{nM}$, respectively. Many reports have suggested that the presence of the en-1-one moiety in ring $A$ and the $5 \beta, 6 \beta$-epoxide moiety in ring B increase the activity profile of the withanolides. Among the epoxy derivatives of 104c, i.e., compounds 106a and 107 (Figure 13), compound 106a, with the $\beta$-epoxide ring, showed improved activities against the two prostate cancer cell lines, with $\mathrm{IC}_{50}$ values of 20 and $90 \mathrm{nM}$, respectively. In contrast, $\alpha$-epoxidation (as in 107) caused a significant loss of cytotoxic activity. Comparing compounds 104-107, containing a $17 \alpha$ side chain and a $17 \beta$-hydroxyl group, with WA bearing a $17 \beta$ side chain, suggested that the orientation of the side chain and/or the presence of the $\mathrm{OH}$ group at $\mathrm{C}-17$ may be partly responsible for their significant selectivity to the prostate cancer cell lines, especially LNCaP, compared to other cancer cell lines. In addition, the $\mathrm{IC}_{50}$ data of physachenolide C (106a) and its 18-deacetoxy analog (106b) [108] suggested that the presence of the OAc group at C-18 and/or the absence of the $\mathrm{OH}$ group at C-4 in 106a caused about a 15-fold enhancement in cytotoxic activity for the LNCaP cell line.
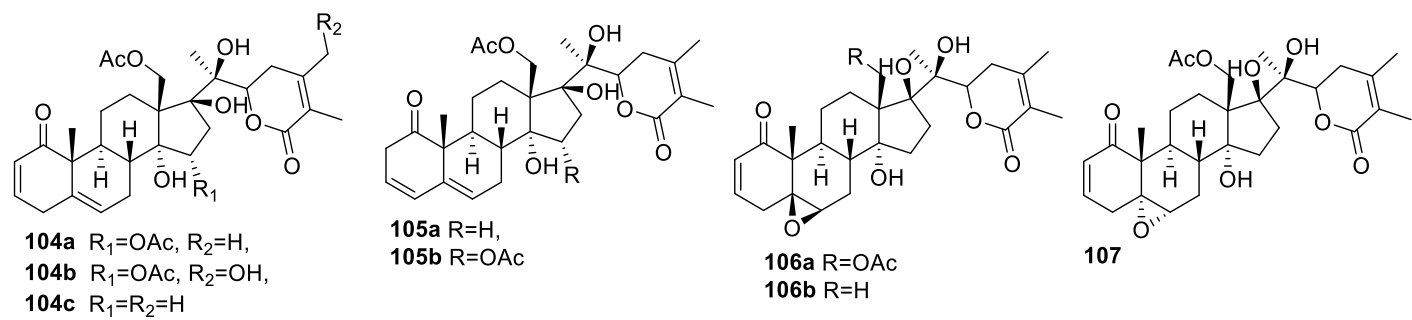

Figure 13. Withanolides isolated from Sonoran desert plants.

\subsection{Synthetic Analogs of Withanolides}

The diverse nature of naturally occurring withanolides presents an equally diverse opportunity to design new analogs with enhanced potency, bioavailability, and reduced toxicity. Therefore, there have been several reports on their modification in the past few decades, including nucleophilic/Micheal addition and hydroxy group modification, leading to a variety of mono-, di-, and tri-substituted withanolides.

\subsubsection{Monosubstituted Withanolides}

The mono-substituted withanolides primarily involve modifications of the withanolides skeleton at C-27, C-4, and C-3.

Modification at the C-27 Position

Bazzocchi and co-workers designed and synthesized a library of WA analogs (108-113) (Figure 14) in an attempt to increase its anti-cancer activity profile [46]. The synthesis mainly 
involved the modifications of the hydroxyl groups, enone system, and $5 \beta, 6 \beta$-epoxy groups (Figure 15). The compounds were evaluated for their anti-proliferative activity against HeLa, A-549, MCF-7, and non-tumoral (Vero) cell lines. All the synthesized analogs showed good to moderate activity profiles-most of the compounds displayed $\mathrm{IC}_{50}$ values ranging from 0.2 to $9.6 \mu \mathrm{M}$ in all the tested tumor cell lines. A SAR study revealed that compounds having $\alpha, \beta$-unsaturated ring A with $5 \beta, 6 \beta$-epoxide in ring B and the $\alpha, \beta$-unsaturated lactone group were the most potent compounds. Compounds with the ester group at the C-27 position were, in general, more active than the non-ester group (WA). Compounds with alkyl esters 108-110 showed activities with $\mathrm{IC}_{50}$ values of 0.3 to $2.6 \mu \mathrm{M}$ against all the tested cancer cell lines. The replacement of the alkyl chain on the ester group with the non-substituted benzene ring led to the most promising anti-proliferative compound 111, with $\mathrm{IC}_{50}$ values $0.3-1.6 \mu \mathrm{M}$ that was attributed to the $\pi-\pi$ interaction with the binding site. The addition of electron-withdrawing/donating groups on the benzene 112-113 ring decreased the anti-proliferative activity. The most active derivatives (110 and 111) induced apoptosis in HeLa cells in a dose- and time-dependent manner, evidenced by chromatin condensation, PS externalization, and caspase-3 activation [109].
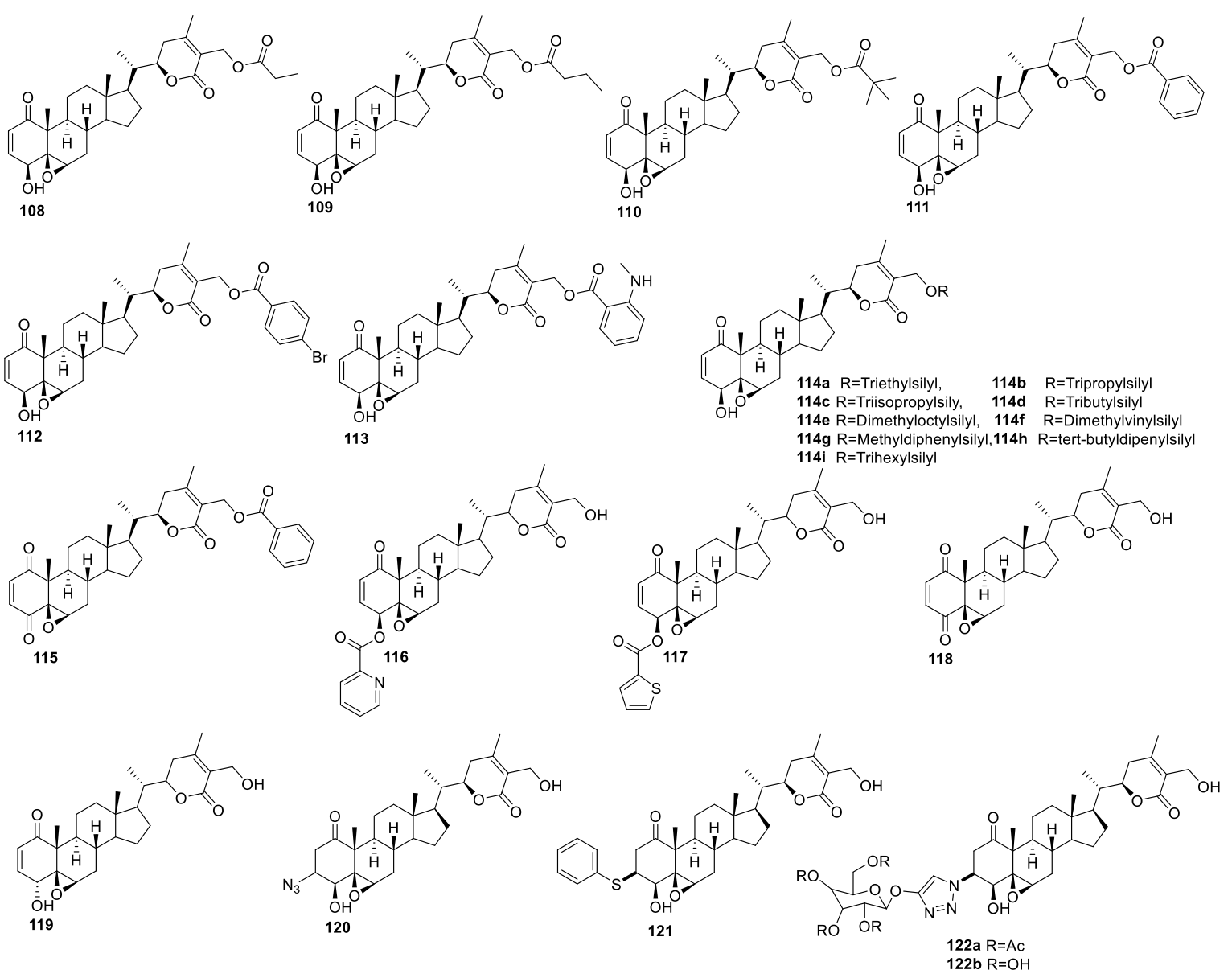

Figure 14. Monosubstituted analogs of WA.

The same group further designed and synthesized a library of WA-silyl ether-linked compounds [110] and evaluated them for their in vitro anti-proliferative activity against human epithelial ovarian tumor cell lines, e.g., cisplatin-sensitive (A2780), cisplatin-resistant (A2780/CP70), and non-carcinoma cell lines (ARPE19). Compounds 114a-I ( $\mathrm{IC}_{50}$ values ranging from 7.3-32 nM) (Figure 14) were more cytotoxic than WA ( $\mathrm{IC}_{50} 32.7 \mathrm{nM}$ ) and reference drug carboplatin $\left(\mathrm{IC}_{50} 2.6 \mu \mathrm{M}\right.$ ) against the cisplatin-sensitive cell line (A2780). The silyl ether-bearing analog with a dimethyloctyl moiety (114e) was 3.2 times more 
potent $\left(\mathrm{IC}_{50}=10 \mathrm{nM}\right)$ than WA. Compound 114i, having a trihexylsilyl moiety at the C-27 position, resulted in complete loss of activity, while compounds $114 a, 114 b$, and 144d were more potent than WA and showed $\mathrm{IC}_{50}$ values in the range of 12.8-32.0 nM. SAR studies on a cisplatin-sensitive cell line (A2780) revealed that compounds with heterogeneous alkyl substituents on the silyl ether $\mathbf{1 1 4 f}-\mathbf{i}$ were slightly more cytotoxic than those with the homogeneous silyl ether 114a-d. Regarding the cisplatin-resistant cell line (A2780/CP70), SAR studies of this series of analogs revealed that compounds carrying a heterogeneous alkyl substituent on the silyl ether (114f-i) displayed similar profiles ( $\mathrm{IC}_{50}$ 24.9-33.0 nM) to WA, indicating that activity was not greatly influenced by their corresponding silyl ether moiety on the withanolide skeleton.

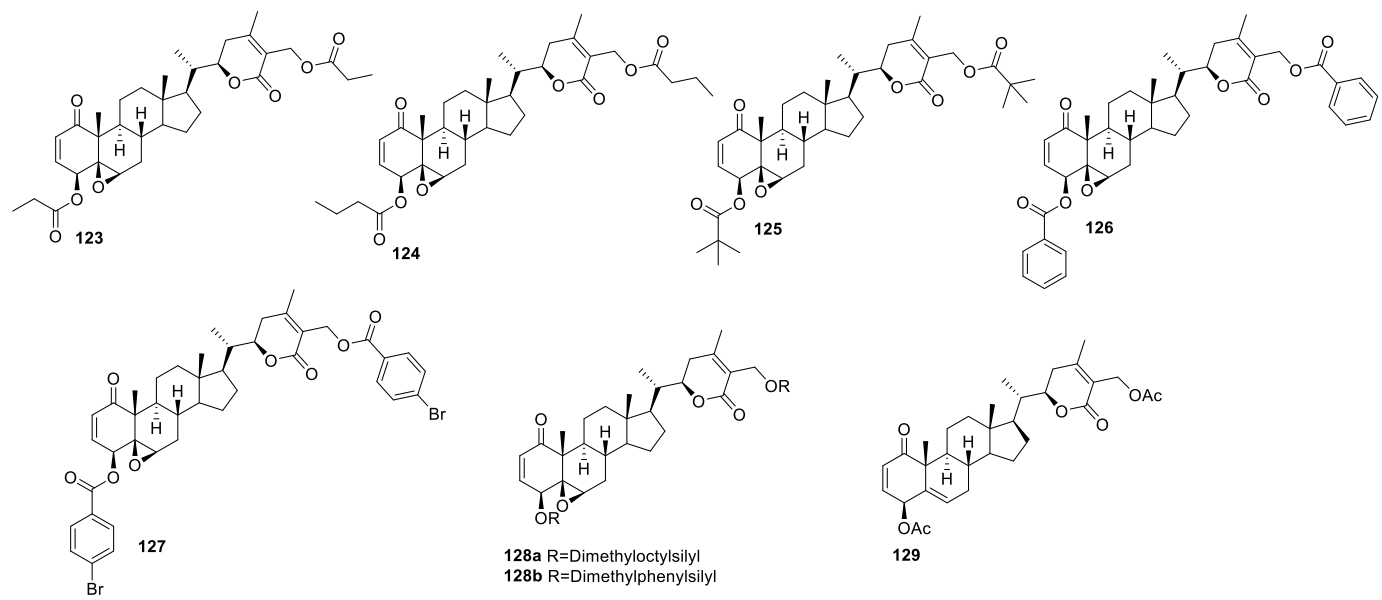

Figure 15. Disubstituted analogs of WA.

Modifications at the C-4 Position

It has been shown that the conversion of the C-4 hydroxy group of $\mathbf{1 1 1}$ to ketone 115 (Figure 14) reduced the anti-proliferative activity, with $\mathrm{IC}_{50}$ values in the range of 1.1-5.4 $\mu \mathrm{M}$ against HeLa, A-549, MCF-7, and non-tumoral (Vero) cell lines [46]. E. M. Kithsiri Wijeratne and co-workers have isolated and semi-synthesized withanolide analogs using microbial and chemical transformation, evaluated them for their cytotoxic activity, and compared them for cytoprotective heat-shock-inducing activity [111]. All the analogs were evaluated for their acute cytotoxicity on human Ewing's sarcoma cell line CHP-100 using doxorubicin and DMSO as the positive and negative controls. The SAR revealed that the nature of the substituents at the C-4 position had directly affected cytotoxicity. Compounds with a carbonyl group at the C-4 position (118, Figure 14), rather than hydroxyl, were inactive compared to WA. The orientation of the $\mathrm{OH}$ group in $\mathbf{1 1 5}$ had little effect on the cytotoxicity ( $\mathrm{IC}_{50} 0.93 \mu \mathrm{M}$ toward CHP-100 cells compared to WA $\left(\mathrm{IC}_{50} 0.97 \mu \mathrm{M}\right)$ ).

Recently, our group was also involved in the modification of the WA structure to develop targeted cancer therapies. This effort has led to several novel analogs with varying degrees of anti-cancer potency (unpublished results). Two of the C4-ester linked compounds reported so far, ASR490 (116) and ASR488 (117) (Figure 14), have demonstrated promising therapeutic potential against colorectal and bladder cancers, respectively [51,112]. The 2-pyridyl ester-linked ASR490 (116) showed the robust growth inhibition of HCT116 and SW620 colon cancer cell lines via the downregulation of the Notch1 signaling pathway. Further, it effectively inhibited tumor growth in control (pCMV/HCT116) and Notch1/HCT116 xenotransplanted mice without any apparent systemic toxicity. The 2-thiophene esterlinked analog ASR488 (117) was selectively toxic to bladder cancer cells, while it was relatively non-toxic to normal cells [112]. These reports attest to the therapeutic potential of appropriately designed WA analogs. 


\section{Modifications at the C-3 Position}

Mukherjee et al. [113] synthesized a small library of compounds (120-122, Figure 14) by regio- and stereo-selective Michael addition to ring A of WA. Ring A of WA was also derivatized by triazoles ring using a $\mathrm{Cu}(1)$-catalyzed 1,3-dipolar cycloaddition reaction with various alkynes. All the synthesized compounds were evaluated for their in vitro anti-proliferative activities against lung, ovary, colon, and prostate cancer cell lines at various concentrations using the SRB assay. Compounds 120, 121, and 122 were the most potent of all the synthesized series of compounds against the tested cancer cell lines. SAR studies revealed that a compound with the azide group on ring A (122) was significantly more potent than its parent compound, with an $\mathrm{IC}_{50}$ value of $0.02-1.9 \mu \mathrm{M}$. The activity of the compounds also depended upon the side chain compound 122a, bearing a galactose moiety, which showed comparable cytotoxicity to WA. Increasing the hydrophilicity by deacetylating 122a to $\mathbf{1 2 2 b}$ resulted in a deleterious effect on growth inhibition. Among the thio group containing analogs, compounds 121 with thiophenol functionality at the C-3 position in ring $\mathrm{A}$ was the most potent, with $\mathrm{IC}_{50}$ values in the range of $0.13-2.2 \mu \mathrm{M}$ against the tested cell lines.

\subsubsection{Disubstituted Withanolides}

The disubstituted withanolides mainly include modification at C-4 and C-27 positions of the withanolide skeleton. In all the cases, generally, the substitution is identical at both the C-4 and C-27 positions because the reaction conditions used for their synthesis lead non-specifically to the acylation of both the hydroxyl groups at C-4 and C-27. Bazzocchi and group synthesized diester derivatives 123-129 (Figure 15) using DMAP-promoted acid chloride/acid anhydride coupling with WA [46]. These diesters were marginally less potent than their monoester derivatives, having $\mathrm{IC}_{50}$ values in the range of $0.6-4.6 \mu \mathrm{M}$ against HeLa, A-549, and MCF-7 cells. For example, compound $123\left(\mathrm{IC}_{50} 1.1-4.1 \mu \mathrm{M}\right)$ was slightly less active compared to its monoester derivative $108\left(\mathrm{IC}_{50} 1.1-2.3 \mu \mathrm{M}\right)$ against all the tested cell lines. Disilyl ether containing derivatives of WA were more active than the parent compound WA in human epithelial ovarian tumor cell lines, e.g., cisplatin-resistant (A2780/CP70) and non-carcinoma cell lines (ARPE19). Derivatives 128a (IC $501.5 \mathrm{nM}$ ) and $\mathbf{1 2 8 b}\left(\mathrm{IC}_{50} 2.9 \mathrm{nM}\right)$ were substantially more potent than the parent compound WA $(32.2 \mathrm{nM})$ and exhibited comparable potency to the standard drug carboplatin (2.6 nM) in cisplatinsensitive A2780 cells. However, these compounds were only slightly more active, with $\mathrm{IC}_{50}$ values of 24.9 and $29.0 \mathrm{nM}$, respectively, than the parent compound WA, having an $\mathrm{IC}_{50}$ value of $32.0 \mathrm{nM}$ against cisplatin-resistant A2780/CP70 cells. These compounds were also evaluated against a non-carcinoma cell line (ARPE19) to determine their selectivity; compounds 128a and 128b showed good selectivity (selectivity index value $>2$ ) in the non-carcinoma cell line (ARPE19) to A2780 cells. The importance of the epoxy group in the $\mathrm{B}$ ring for cytotoxicity has been reported [78,96]. However, the replacement of the epoxy group with a double bond in $\mathbf{1 2 9}$ retained the activity $\left(\mathrm{IC}_{50} 0.53 \mu \mathrm{M}\right)$ against human Ewing's sarcoma cell lines (CHP-100 cells), which provides the evidence that the epoxy ring may not be the main contributing factor for cytotoxicity against CHP-100 cells [111].

\subsubsection{Trisubstituted Withanolides}

There are several reports on the synthesis and biological evaluation of trisubstituted withanolides, bearing substitution, in most cases, at the C-27, C-4, and C-19 positions. Motiwala and co-workers synthesized a series of mono-, di-, and tri-substituted WA analogs, 130-137 (Figure 16), and evaluated them for their cytotoxicity against head and neck squamous cell (HNSCC, JMAR), breast cancer (MDA-MB-231), melanoma (SKMEL-28), colon cancer (DRO81-1), and normal fetal lung fibroblast (MRC-5) cells [114]. Di- and tri-acetate analogs 130e and 131 exhibited enhanced cytotoxic activity compared to monoacetate analogs 130a, 130b, and 130c. Notably, compound 130e was found to be particularly more cytotoxic toward DRO81-1, with an $\mathrm{IC}_{50}$ value of $0.0580 \mu \mathrm{M}$. The tripropionylated analog 131 was also active, with $\mathrm{IC}_{50}$ values in the range of $0.130-1.00 \mu \mathrm{M}$. The increased cyto- 
toxicity of the di- and triacetate analogs of the compound WA could be due to increased lipophilicity, leading to enhanced cell permeability [79,115,116]. Compound $\mathbf{1 3 2}$ showed $3-5$ times increased activity, with $\mathrm{IC}_{50}$ values of 0.175 and $0.205 \mu \mathrm{M}$ against breast cancer and melanoma cells, respectively, compared to $\mathrm{WA}$, with $\mathrm{IC}_{50}=0.540$ and $1.00 \mu \mathrm{M}$, while jaborosalactone $\mathrm{V}$ diacetate $\mathbf{1 3 3}$ was found to be equipotent to WA, suggesting that the C-4 hydroxyl group is not crucial for activity [8,78]. 2-Iodo analog 136 was inactive, with $\mathrm{IC}_{50}$ values of in the range of $5.25 \mu \mathrm{M}->10 \mu \mathrm{M}$ compared to its parent compound, 134, with $\mathrm{IC}_{50}$ values of $1.50 \mu \mathrm{M}-5.30 \mu \mathrm{M}$ against all the tested cell lines. On the other hand, analog 137 showed $\mathrm{IC}_{50}$ values in the range of $0.11-0.83 \mu \mathrm{M}$ against all the tested cancer cell lines, which were equally potent to its precursor compound 135 . Macrocycle 139 exhibited increased potency compared to its acyclic analog 136 across all cell lines tested, with $\mathrm{IC}_{50}$ values in the range of $0.205-0.965 \mu \mathrm{M}[117,118]$. Most of the active compounds were moderately selective toward cancer cells compared to normal fibroblast cells.
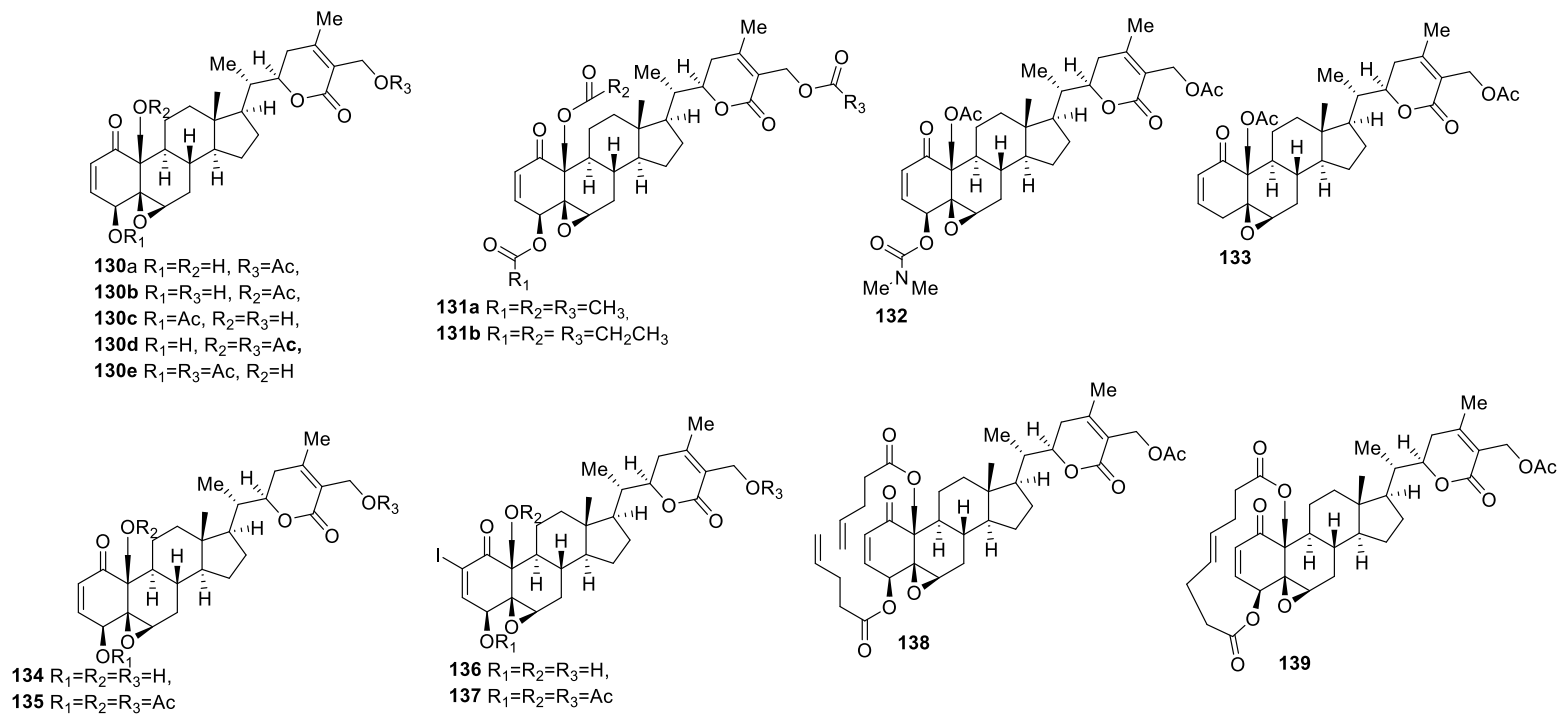

Figure 16. Trisubstituted analogs of WA and related mono- and di-substituted compounds studied for comparison.

\subsubsection{Fused Withanolide Analogs}

The Faheem Rasool group synthesized novel withaferin A-ring-condensed, 2-isoxazoline derivatives [119]. The rationale for designing 2-isoxazoline-fused withanolides was that this moiety has been known as a building block for biologically active molecules and an essential precursor in organic reactions [120]. The synthesized compounds were evaluated for their anti-proliferative activity against MCF-7 and HCT-116 cell lines. All the derivatives showed significant activity against both the tested cancer cell lines. The fused nitro isoxazolines 140 (Figure 17), having a $\beta, \beta$-ring juncture, were found to be more potent against MCF-7 and HCT-116 cell lines, with $\mathrm{IC}_{50}$ values $0.70 \mu \mathrm{M}$ and $1.25 \mu \mathrm{M}$, respectively, compared to fused nitro isoxazolines $\mathbf{1 4 1}$ with an $\alpha, \alpha$-ring juncture, with $\mathrm{IC}_{50}$ values of 5.82 and $8.2 \mu \mathrm{M}$, respectively.
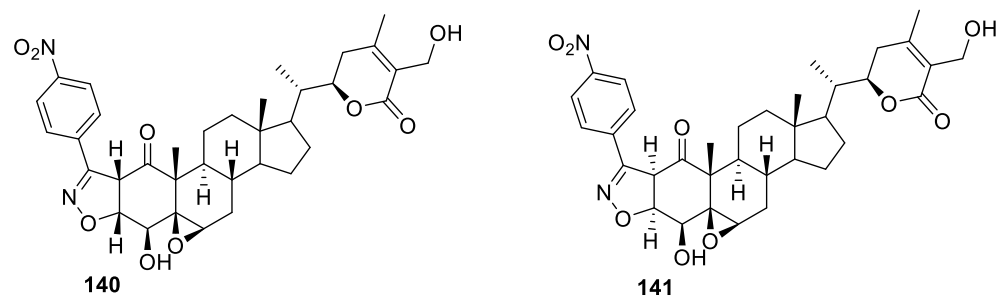

Figure 17. Fused analogs of WA. 


\subsubsection{Generally Adapted Synthetic Approaches}

Because of the difficulty in synthesizing sterocontrolled withanolide skeletons, most synthetic modifications have been performed starting from a parent withanolide, WA in most cases, using simple synthetic transformations that mainly include the acylation of hydroxy groups at C4 and C27 and a Michael addition to form 3-substituted withanolides (Figure 18). The only interesting synthetic feature that is worth highlighting is the acylation of primary (C-27) vs. secondary (C-4) hydroxyl groups in withanolide structures that can be manipulated based on the reaction conditions used to lead to exclusive or a mixture of mono-primary or secondary hydroxyl group acylations or disubstituted products [114]. For example, the use of acetic anhydride as an acylating agent and pyridine as the base in the presence of DMAP in the acylation of WA [111] led to a mixture of mono-acylated (C-27) and di-acylated (C-4 and C-27) products. A similar pattern was observed for reaction with acid chlorides and trimethylamine and DMAP, which also resulted in a mixture of mono-acylated (C-27) and di-acylated (C-4 and C-27) products [46]. Protection of the primary hydroxyl group was necessary to accomplish the selective acylation of the secondary (C-4) hydroxyl group of WA in these cases. Interestingly, similar reactions of acid chlorides and trimethylamine in the absence of DMAP result in an exclusive formation of the C-4-acylated product, as demonstrated by the selective acylation of the C4-hydroxyl group with excess dimethylcarbamoyl chloride [114] and pyridine-2-carbonyl chloride hydrochloride. However, acylating behavior could also depend on the nature of the acid chloride, as the use of $p$-chlorobenzoyl chloride under similar conditions led to a mixture of compounds with acylation at C-4 and C-27 and multi -OH acylation [114]. Furthermore, sodium-hydride-assisted O-alkylation with methyl iodide led to a mixture of C-4- and C-27-methylated products [46].

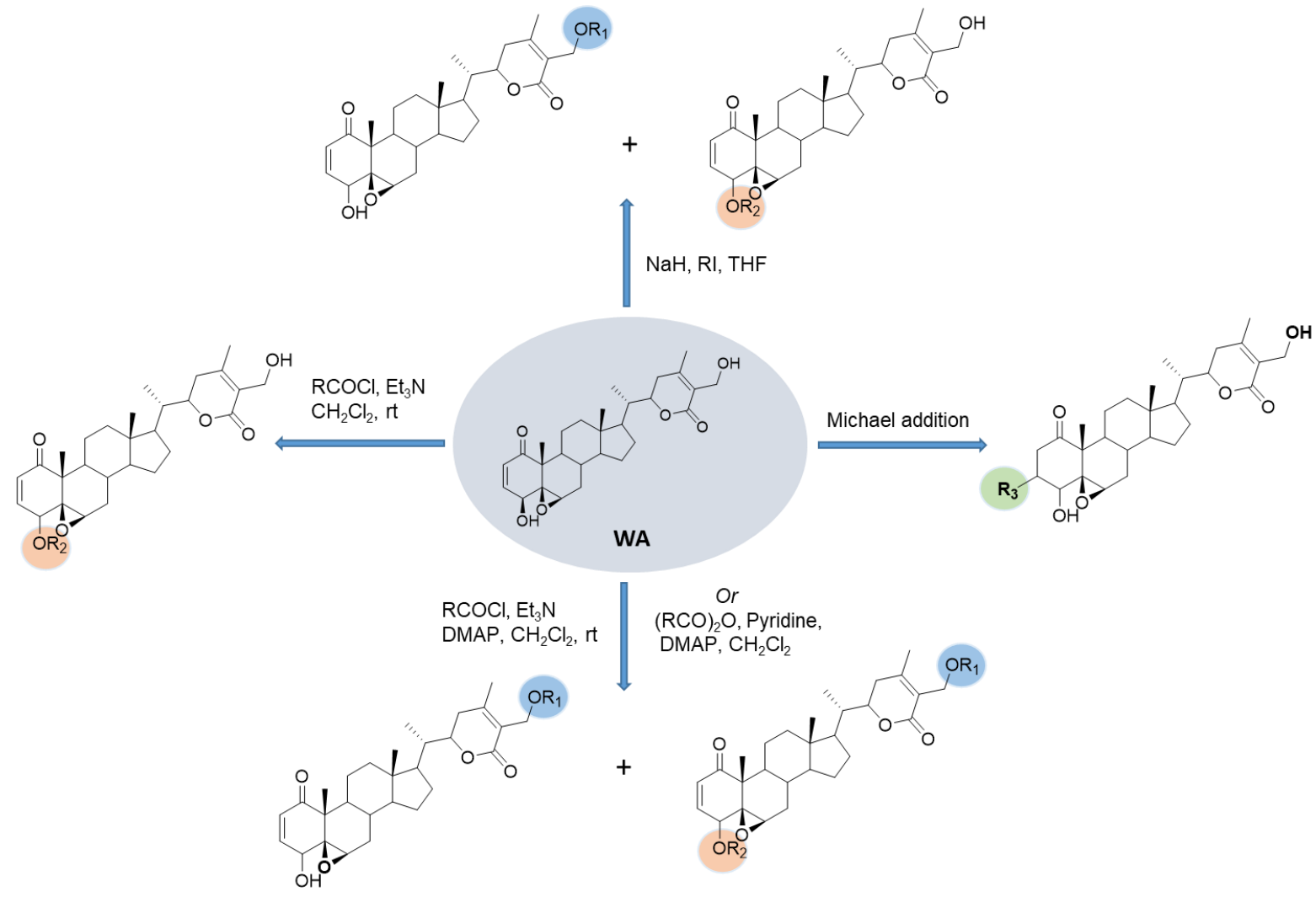

Figure 18. Common synthetic features of withanolide analogs. 


\section{Withanolides as Anti-Inflammatory Agents}

Inflammation is a defensive reaction of the body's immune system against harmful external factors such as bacteria, damaged cells, and irritants [121-123]. However, excessive and inappropriate inflammation contributes to various human diseases such as autoimmune disorders, sepsis, diabetes, and even cancer [124,125]. Macrophages play a vital role in the inflammatory response and serve as an essential interface between innate and adaptive immunity [126]. Inflammation can be acute and chronic in acute inflammation; the movement of plasma and leukocytes from the blood into the injured tissue is increased to combat the harmful stimuli, while chronic or prolonged inflammation leads to a gradual change in the form of the cells present at the site of inflammation, such as mononuclear cells, and is characterized by tissue degradation and recovery from the inflammatory process at the same time. This section describes the literature evidence of the anti-inflammatory properties of withanolides.

Minabeolides, the first class of marine withanolides, were isolated from the soft coral Minabea sp. by Chih-Hua Chao and group [127] and were tested to inhibit lipopolysaccharide (LPS)-induced pro-inflammatory protein (iNOS and COX-2) expression in RAW264.7 macrophage cells. At a concentration of $10 \mu \mathrm{M}$, compounds 142-147 (Figure 19) significantly reduced the levels of iNOS to $11.0 \%, 7.3 \%, 37.9 \%, 43.4 \%, 9.6 \%$, and $45.7 \%$, respectively. However, at this dose, compound 142 showed a decrease of $\beta$-actin $(66.5 \%$ relative to the control group), indicating its cytotoxicity against the tested macrophage cells.
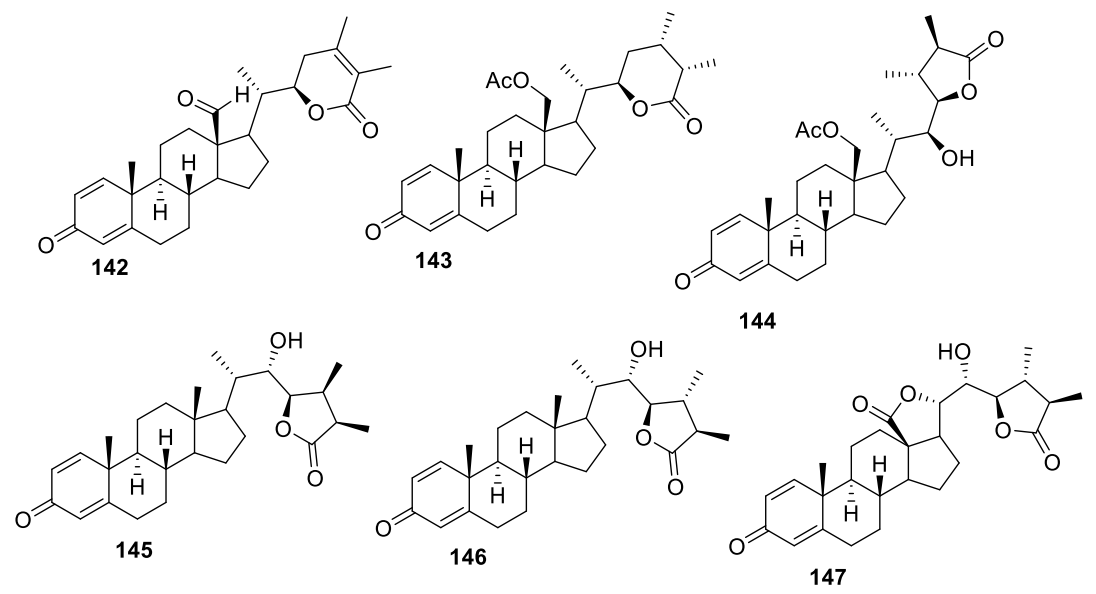

Figure 19. Most potent withanolides from Minabea sp.

The dry flowers of $D$. metel $\mathrm{L}$, called 'Yanginhua', have commonly been used to treat cough, asthma, rheumatism, pain, and convulsions in traditional Chinese medicine for centuries [128]. Withanolides are the main constituents of the flower of D. metel, which have been used for the treatment of psoriasis [129]. However, long fluorescence and low yield were the two main disadvantages of dry flowers of $D$. metel. Yang and co-workers isolated four withanolides from the leaves of this plant, which has the advantage of high yield [130]. All isolates were identified as major active constituents with inhibitory effects of NO production in LPS-activated RAW 264.7 cells, the murine macrophages [131]. The effect of compounds 148-151 (Figure 20) on cell viability was evaluated by the MTT assay to ascertain the absence of cytotoxicity (over $90 \%$ cell survival) to macrophage cells at the concentration of $100 \mu \mathrm{M}$. Compounds $\mathbf{1 4 8}$ and $\mathbf{1 5 1}$ showed a substantial anti-inflammatory effect, with $\mathrm{IC}_{50}$ values of $17.8 \mu \mathrm{M}$ and $11.6 \mu \mathrm{M}$, respectively, compared to L-NMMA $\left(\mathrm{IC}_{50}=13.1 \mu \mathrm{M}\right)$ used as a positive control. Compounds 149 and 150 displayed a moderate anti-inflammatory profile, with $\mathrm{IC}_{50}$ values of 33.3 and $28.6 \mu \mathrm{M}$. 


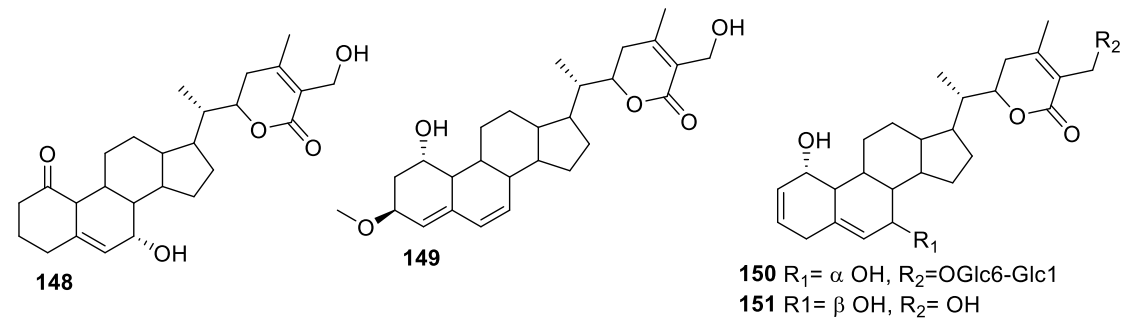

Figure 20. Withanolides isolated from D. metel L.

P. minima is a branched annual shrub that has long been used in traditional medicine in the history of southeastern China with the name 'XiaoSuanJiang' [8]. Its extracts or infusions have been used to treat many diseases, such as cancer, soreness, pyretic symptoms, and inflammation [132]. Several unique withanolides, such as physalins and withaphysalins, were isolated from this plant [133]. Ru Lin et al. isolated four new withanolides, 152-155 (Figure 21), and their structures were confirmed using extensive spectroscopic techniques [102]. These compounds were evaluated for their NO inhibitory effects on LPS-activated RAW 264.7 macrophages to explore their potential anti-inflammatory activity. The MTT assay revealed that all the compounds had no apparent cytotoxic effects on RAW 264.7 macrophages at concentrations of up to $50 \mu \mathrm{M}$. Compounds 153 and 155 were moderately inhibitory, with $\mathrm{IC}_{50}$ values of 25.34 and $20.81 \mu \mathrm{M}$, respectively. Their SAR revealed that 2,5-dien-1-one (153) or 3,5-dien-1-one (155) moieties in rings A and B are essential for the activity. The absence of this double unsaturation, for example, because of the transformation of 5-ene to $5 \alpha, 6 \beta$-diol (e.g., 152 and 154), dramatically reduced their NO inhibitory effects. Compounds with s 2,5-dien-1-one moiety were more active than 3,5-dien-1-one for NO inhibition, consistent with the observations made for previously isolated 13,14-seco-withanolides [134]. Furthermore, the introduction of $15 \alpha-\mathrm{OH}$ resulted in an obvious decrease in the activity. Three new withanolides, physaperuvin G (156), along with physaperuvins I (157) and J (158) (Figure 21), extracted from the aerial part of $P$. peruviana (Poha), showed moderate to no anti-inflammatory activity, with $\mathrm{IC}_{50}$ values in the range of 3-50 $\mu \mathrm{M}$ [135].
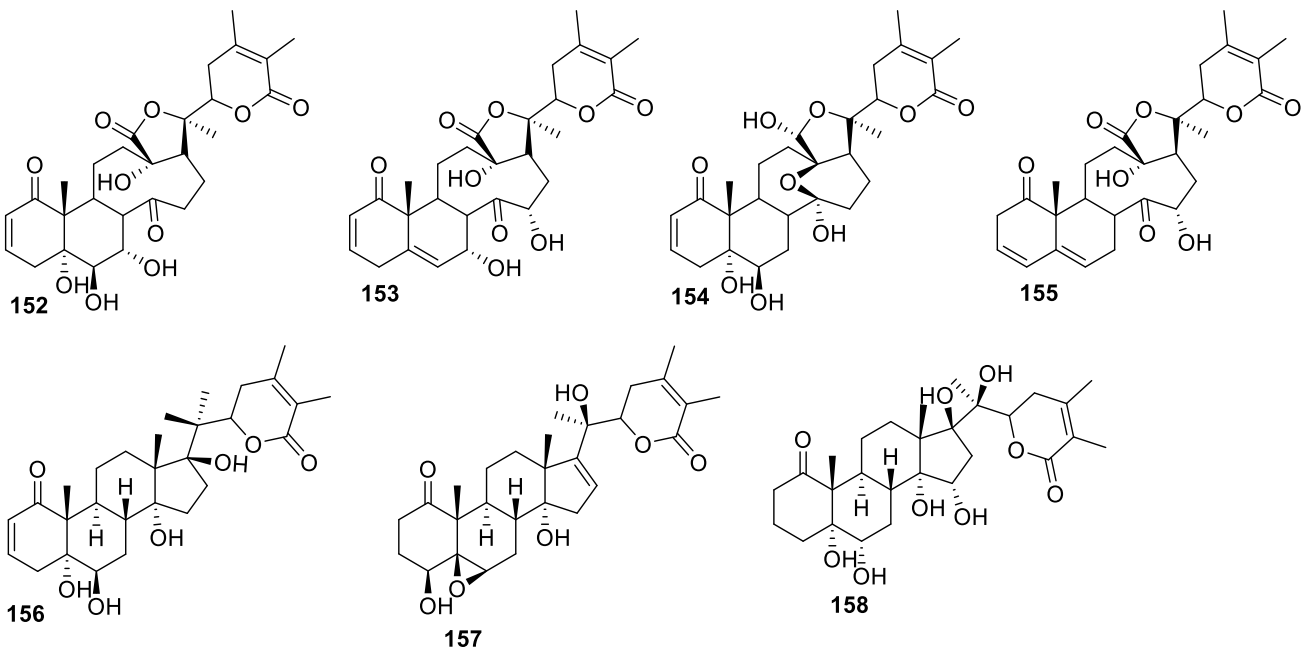

Figure 21. Withanolides isolated from P. minima.

Chiung-Yao Huang and group isolated six new withanolides, 159-164 (Figure 22), from Sinularia brassica using ethyl acetate extraction [136] and evaluated them for their anti-inflammatory activity on neutrophil pro-inflammatory responses by measuring their ability to suppress fMLP/CB-induced superoxide anion $\left(\mathrm{O}_{2}{ }^{-}\right)$generation and elastase release in human neutrophils. Compound 164 was the most potent, with an $\mathrm{IC}_{50}$ value 
of $3.5 \mu \mathrm{M}$ against super anion generation and $1.4 \mu \mathrm{M}$ against elastane release in human neutrophils. On the other hand, compounds 159-163 showed a moderate activity profile, with an $\mathrm{IC}_{50}$ value greater than $10 \mu \mathrm{M}$ for both studies.

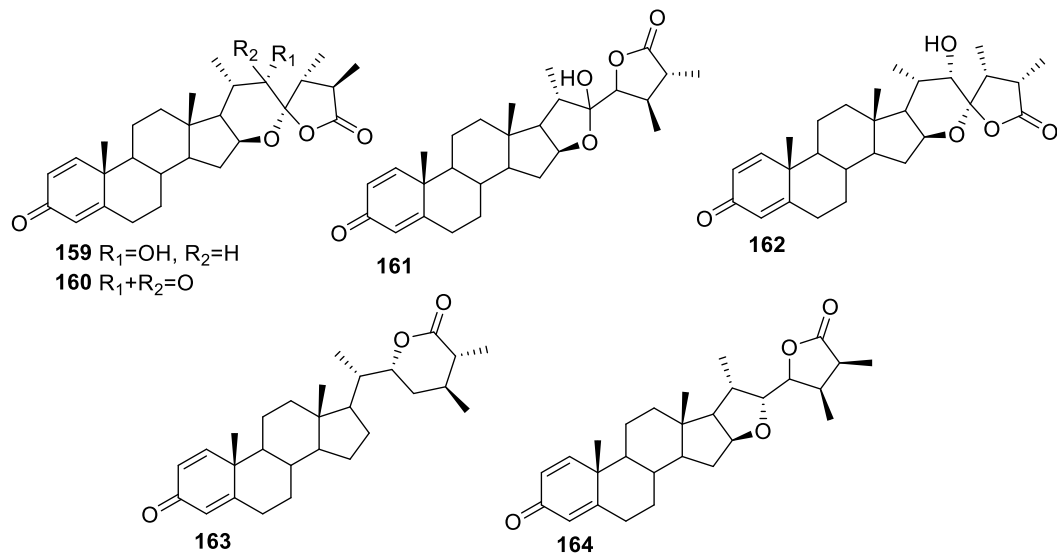

Figure 22. Withanolides isolated from Sinularia brassica.

Annual herb Nicandra physaloides (N. physaloides; Solanaceae family) originates in Peru and is also distributed in Yunnan, Guangxi, Guizhou, and other places in China [137]. The whole plant of $N$. physaloides is used as medicine, especially as a sedative, expectorant, antipyretic, and antidote in China $[138,139]$. Phytochemical studies revealed that N. physaloides contained large amounts of withanolides [140,141] and aromatic glycosides [142], with anti-tumor [143], anti-inflammatory [144], and other pharmacological effects. Because of the medicinal property of this herb, Peng Zhang isolated two new withanolides, 165-166 (Figure 23), and evaluated them for their inhibitory effects on NO production induced by LPS in a mouse macrophage cell line RAW 264.7, using hydrocortisone and dexamethasone as positive controls. Both the compounds showed low to moderate activity, with $\mathrm{IC}_{50}$ values of 58.79 and $7.90 \mu \mathrm{M}$ [137].

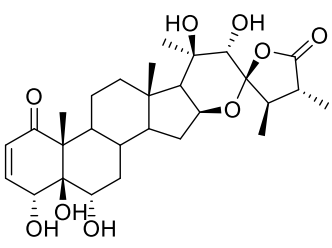

165

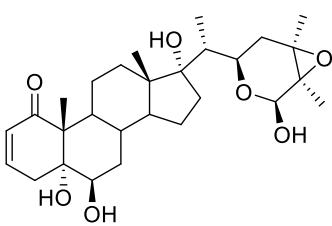
169

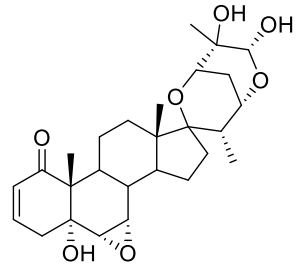

166

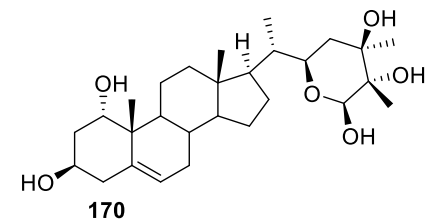

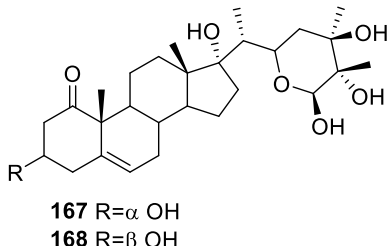

$168 \mathrm{R}=\beta \mathrm{OH}$

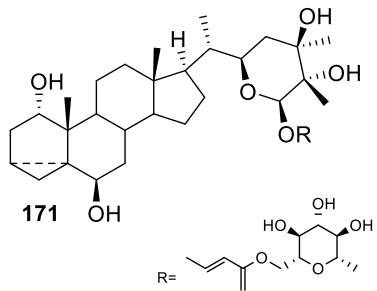

Figure 23. Withanolides isolated from N. physaloides and S. capsicoides.

Five new capsisteroids, 167-171 (Figure 23), were isolated from S. capsicoides by YouCheng Lin and co-workers [145]. The in vitro pro-inflammatory efficacy of the newly isolated compounds was tested by evaluating the suppression of $N$-formyl-methionylleucylphenylalanine/cytochalasin B (fMLF/CB)-induced superoxide anion $\left(\mathrm{O}_{2}{ }^{-}\right)$generation and elastase release in human neutrophils. At a concentration of $30 \mu \mathrm{M}$, compounds 168 and 169 were found to inhibit superoxide anion generation $(14.8 \%$ and $20.9 \%$, respectively). Additionally, compound 170 displayed $42.9 \%$ inhibition toward elastase release. 
The new undescribed withanolides, daturmetelides 172-180 (Figure 24), were isolated from the leaves of $D$. metel L. and were evaluated for their anti-inflammatory activity [146] and mechanism of action. Compounds 172-180 were the only active compounds of all the tested compounds, with moderate effect against NO production. Compound $\mathbf{1 7 2}$ showed an $\mathrm{IC}_{50}$ value of $13.7 \mu \mathrm{M}$ against Raw 264.7 cells. From the SAR study, the authors deduced that both the $4 \beta$-hydroxy-2-en-1-one unit in ring $\mathrm{A}$ and a conjugated diene system in rings $A$ and $B$ led to enhanced anti-inflammatory ability. These results further validate that the presence of the 2(3)-en-1-one moiety in ring A plays an essential role in the antiinflammatory activity, which is consistent with previous reports [135].
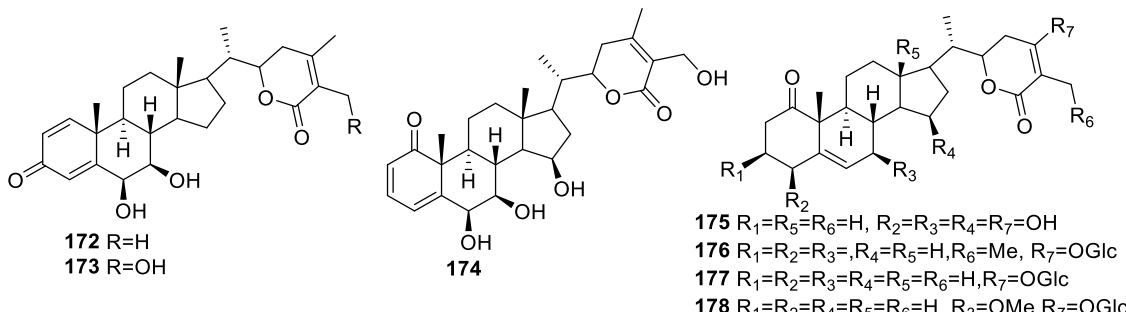

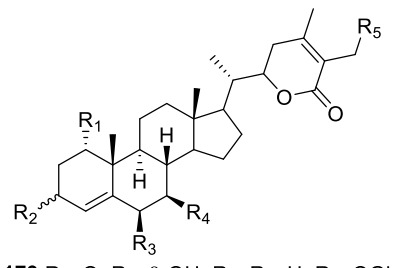

$179 \mathrm{R}_{1}=\mathrm{O}, \mathrm{R}_{2}=\beta-\mathrm{OH}, \mathrm{R}_{3}=\mathrm{R}_{4}=\mathrm{H}, \mathrm{R}_{5}=\mathrm{OGlc}$ $180 \mathrm{R}_{1}=\mathrm{O}, \mathrm{R}_{2}=\alpha-\mathrm{OH}, \mathrm{R}_{3}=\mathrm{R}_{4}=\mathrm{H}, \mathrm{R}_{5}=\mathrm{OGIC}$

Figure 24. Withanolides isolated from D. metel L.

\section{Withanolides as Antibacterial Agents}

Nicandra Adans. (Solanaceae), a small genus, has three species, namely, Nicandra johntyleriana S. Leiva, Pereyra, and Nicandra yacheriana S. Leiva [147-149]. Eleven new withanolides, 181-191 (Figure 25), were isolated by Nicolas et al. and were evaluated for the antibacterial activity against different strains of Bacillus, Enterococcus, Escherichia, Listeria, Pseudomonas, and Staphylococcus by utilizing a disk diffusion method and bioautography [147]. Compounds 182 and 186 demonstrated effective antibacterial activity against Bacillus. The antibacterial activity of compound 182 was also quantified by direct contact against $B$. cereus BAC1 cells. This compound exerted bactericidal and bacteriostatic effects at 1000 and close to 750 ppm, respectively.
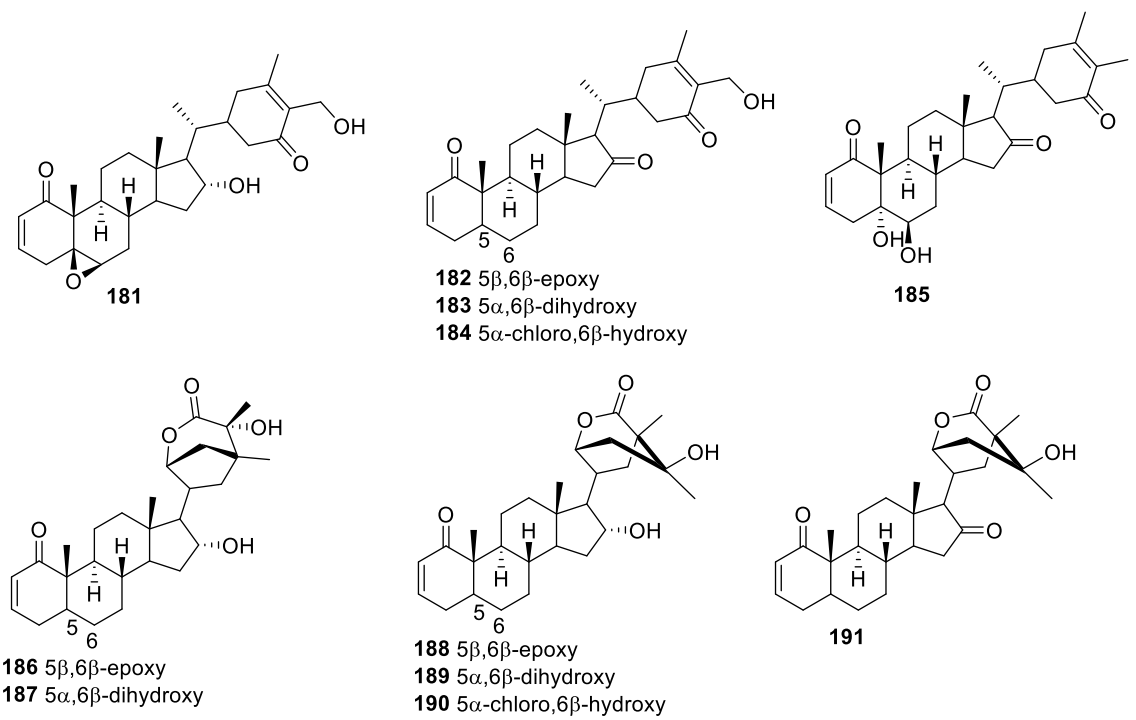

Figure 25. Withanolides isolated from Nicandra Adans.

\section{Withanolides as Anti-Leishmaniasis Agents}

In addition to anti-cancer, anti-inflammatory, and anti-bacterial properties, there have been reports of withanolides acting as potential anti-leishmaniasis agents. Leishmaniasis is a parasitic disease occurring in tropical, subtropical, and southern Europe. It is caused 
by Leishmania parasite infection, which is transmitted by the bite of phlebotomine sand flies [150]. Masanori Kuroyanagi and group isolated four new withanolides from the aerial part of $W$. coagulanes and evaluated them for their leishmanicidal activity against L. major promastigotes [151]. Compounds 192-195 (Figure 26) showed $\mathrm{IC}_{50}$ values of 15.9, 50.0, 5.1, and $53.0 \mu \mathrm{g} / \mathrm{mL}$, respectively, with compound 194 being the only active compound with an $\mathrm{IC}_{50}$ value of $5.1 \mu \mathrm{g} / \mathrm{mL}$.

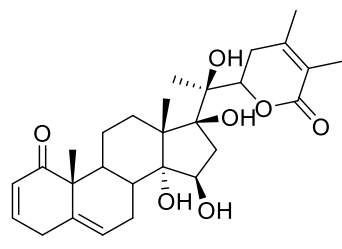

192

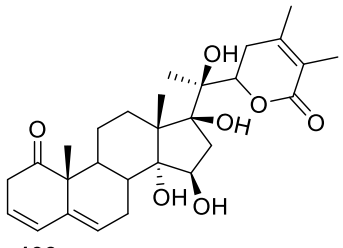

193

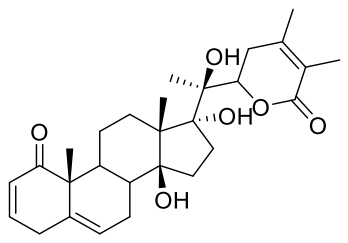

194

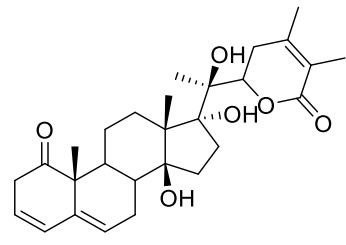

195

Figure 26. Withanolides isolated from $W$. coagulanes.

\section{Conclusions}

Plants are a rich source of naturally occurring small molecules of medicinal importance that make valuable leads for drug discovery. For example, withanolides are naturally occurring C-28 steroid lactones, which have shown tremendous potential as preventive/therapeutic agents for cancer and several other diseases (Table 1). In addition, these compounds are rich in oxygenated functions that provide ample opportunity for structural modifications in order to design more efficacious drug-like molecules. Most of the withanolides have been extracted from the Solanaceae family. Traditionally, leaves and barriers of the Ashwagangha (Withania somnifera) plant have been used as a remedy for treating several health conditions. Among withanolides, WA is the most active compound that is mainly responsible for the biological activity of Ashwagandha.

Table 1. Source and activity of natural withanolides.

\begin{tabular}{|c|c|c|c|c|}
\hline Genus & Species & Scaffold & Activity Against & References \\
\hline Acnistus & arborescens & Withanolides 91-94 (Figure 12) & $\begin{array}{l}\text { Leukemia, colon, } \\
\text { adenocarcinoma, glioblastoma, } \\
\text { and pancreas carcinoma }\end{array}$ & [99] \\
\hline \multirow{5}{*}{ Datura } & inoxia & Dinoxin B 54 (Figure 9) & $\begin{array}{l}\text { Breast, lung, colon, liver, } \\
\text { melanoma, and ovarian cancer }\end{array}$ & {$[81]$} \\
\hline & \multirow{3}{*}{ metel L } & Daturanolides 61-63 (Figure 9) & $\begin{array}{l}\text { Colon, lung, glioma, liver, and } \\
\text { human gastric cancer }\end{array}$ & {$[84]$} \\
\hline & & Withanolides 148-151 (Figure 20) & Inflammation & {$[131]$} \\
\hline & & Daturmetelides 172-180 (Figure 24) & Inflammation & {$[146]$} \\
\hline & wrightii & Withanolides 56-60 (Figure 9) & $\begin{array}{c}\text { Human glioblastoma, head } \\
\text { and neck squamous cell } \\
\text { carcinoma }\end{array}$ & {$[83]$} \\
\hline Deprea & subtriflora & Withanolides 100-103 (Figure 12) & $\begin{array}{l}\text { Lung, cervical, breast, and } \\
\text { colon cancer }\end{array}$ & {$[104]$} \\
\hline Dioscorea & japonica & $\begin{array}{c}\text { Dioscorolide A } 78 \text { and } \\
\text { dioscorolide B } 79 \text { (Figure 11) }\end{array}$ & $\begin{array}{l}\text { Lung, ovarian, melanoma, and } \\
\text { colon cancer }\end{array}$ & {$[94]$} \\
\hline Eriolarynx & iochromoides & Withanolides 100-103 (Figure 12) & $\begin{array}{l}\text { Lung, cervical, breast, and } \\
\text { colon cancer }\end{array}$ & {$[104]$} \\
\hline Morocco & W. frutescens & Withanolides 69-71 (Figure 10) & Colon adenocarcinoma & [90] \\
\hline Nicandra & physaloides & Withanolides 165-166 (Figure 23) & Inflammation & {$[137]$} \\
\hline
\end{tabular}


Table 1. Cont.

\begin{tabular}{|c|c|c|c|c|}
\hline Genus & Species & Scaffold & Activity Against & References \\
\hline & $\begin{array}{c}\text { john-tyleriana S. Leiva, } \\
\text { Pereyra and } \\
\text { yacheriana S. Leiva }\end{array}$ & Withanolides 181-191 (Figure 25) & Bacteria & [147-149] \\
\hline Paraminabea & $\begin{array}{l}\text { acronocephala } \\
\text { (Soft coral) }\end{array}$ & $\begin{array}{l}\text { Paraminabeolides 142-147 } \\
\text { (Figure 19) }\end{array}$ & Inflammation & [127] \\
\hline \multirow{8}{*}{ Physalis } & angulate & Withanolides 16 and 17 (Figure 2) & $\begin{array}{l}\text { Prostate, renal, and } \\
\text { melanoma cancer }\end{array}$ & [65] \\
\hline & angulata var & Withanolides 5-9 (Figure 2) & Breast and liver cancer & {$[63]$} \\
\hline & crassifolia & Withanolids 39-42 (Figure 6) & $\begin{array}{c}\text { Prostate adenocarcinoma, } \\
\text { breast adenocarcinoma, } \\
\text { non-small-cell lung cancer, and } \\
\text { CNS glioma }\end{array}$ & [75] \\
\hline & longifolia & Withanolides 25-34 (Figure 4) & $\begin{array}{l}\text { Head and neck squamous cell } \\
\text { carcinoma and melanoma }\end{array}$ & [71] \\
\hline & $\begin{array}{l}\text { minima Linn. } \\
\text { var. indica }\end{array}$ & Withanolides 152-155 (Figure 21) & Inflammation & [102] \\
\hline & neomexicana Rydb & Withanolides 35-38 (Figure 5) & Breast cancer & {$[74]$} \\
\hline & peruviana & Withanolides 50-53 (Figure 8) & $\begin{array}{l}\text { Androgen-sensitive and } \\
\text {-resistant human prostate } \\
\text { adenocarcinoma, human renal } \\
\text { adenocarcinoma, and } \\
\text { human melanoma }\end{array}$ & {$[80]$} \\
\hline & pubescens $L$ & Withanolides 43-49 (Figure 7) & $\begin{array}{c}\text { Prostate cancer, renal } \\
\text { carcinoma, and melanoma }\end{array}$ & [77] \\
\hline \multirow[t]{2}{*}{ Sinularia } & \multirow[t]{2}{*}{ brassica (Soft coral) } & Sinubrasolides 80-86 (Figure 11) & $\begin{array}{l}\text { Murine pre-B-cell lymphoma, } \\
\text { acute lymphoblastic leukemia, } \\
\text { myelogenous leukemia, and } \\
\text { colon cancer }\end{array}$ & [97] \\
\hline & & Withanolides 159-164 (Figure 22) & Inflammation & [136] \\
\hline Solanum & capsicoide & Capsisteroids 167-171 (Figure 23) & Inflammation & [145] \\
\hline Tacca & plantaginea & Sinubrasolides 87-90 (Figure 11) & Liver carcinoma & [98] \\
\hline \multirow{3}{*}{ Withania } & \multirow[t]{2}{*}{ coagulans } & $\begin{array}{c}\text { Dioscorolide A } 78 \text { and } \\
\text { dioscorolide B } 79 \text { (Figure 11) }\end{array}$ & $\begin{array}{l}\text { Inhibition of TNF- } \alpha \text {-induced } \\
\text { NF- } k \text { B activation in human } \\
\text { embryonic kidney cells }\end{array}$ & [93] \\
\hline & & Compounds 192-195 (Figure 26) & Leishmaniasis & [151] \\
\hline & somnifera & Withanolides 72-77 (Figure 10) & $\begin{array}{c}\text { Breast, lung, colon, liver, } \\
\text { prostate, oral, cervical, } \\
\text { pancreatic, and ovarian cancer }\end{array}$ & [92] \\
\hline
\end{tabular}

Naturally occurring withanolides have shown a variety of biological activities. In addition to the anti-cancer, anti-inflammatory, antibacterial, and anti-leishmaniasis activities described in this article, there is ample evidence of the use of natural withanolides in treating depression, fatigue, and insomnia. Furthermore, they inhibit perimenopausal symptoms, improve sperm viability and mobility, and help in back and neck pain syndromes and arthritis. The powdered plant is also a rich source of iron and stimulates the cells of the immune system. In addition to having such diverse biological activities, natural withanolides provide many reactive sites for their structure modification, which can be used to develop more potent and high-yield compounds. Notably, the structure of WA, one of the most active withanolides, has been extensively modified to improve its anti-cancer 
potential. The modifications are mainly carried out on the hydroxyl group at the C-4, C-27 positions and on the enone system at the $\mathrm{C}-3$ position. These synthetic analogs showed a better activity profile than the parent compound WA against HeLa, A-549, and MCF-7 cell lines [46]. Silyl ether linkage of WA also led to an increase in potency compared to WA and standard drug carboplatin against the cisplatin-sensitive A2780 cell line. Silyl ether analogs, having a hydroxyl group at the C-4 position (111), were more potent than analogs having the ketone group at this position (115), indicating that the hydroxyl group may be contributing to the activity in this case [110]. Furthermore, modification on the enone system at the C-3 position also increased the potency of the compound. Analog 120, having the azide group at $\mathrm{C}-3$, was more potent against lung, ovary, colon, and prostate cancer cell lines than WA [113]. In addition, acetate derivatives of WA were also more active than WA-di- and tri- acetate analogs 130 e and 131 were shown to be relatively more potent, with $\mathrm{IC}_{50}$ values ranging $0.11 \mu \mathrm{M}$ to $0.65 \mu \mathrm{M}$ compared to monoacetate analogs $130 \mathrm{a}, 130 \mathbf{b}$, and 130c, having $\mathrm{IC}_{50}$ values of $0.415-3.06 \mu \mathrm{M}$ against head and neck squamous cell (HNSCC, JMAR), breast cancer cells (MDA-MB-231), melanoma (SKMEL-28) and colon cancer (DRO81-1) cells [114]. Among the A-ring-fused isoxazolines, WA analogs, the compounds having a nitro group and $\beta, \beta$ ring juncture (e.g., 138), were shown to be more active than the $\alpha, \alpha$ ring juncture (e.g., 139) against MCF-7 and HCT-116 cell lines [119]. A recent report from our group indicates that C4-acetylated analog ASR490 (116) of WA was significantly more potent than WA in inducing apoptosis in cancer cells. ASR490 effectively inhibited the growth of HCT116 and SW620 colon cancer cell lines by downregulating Notch1 signaling [51]. In addition, ASR490 inhibited the tumor growth in control (pCMV/HCT116) and Notch1/HCT116 xenotransplanted mice without any apparent systemic toxicity. Another C4-acetylated compound, ASR488 (117), inhibited the growth of bladder cancer cells while sparing normal cells. Overall, a careful survey of the literature reports suggests that in most cases, the presence of $\alpha, \beta$-unsaturation in the ring A modification of the hydroxyl groups at the $C-4$ and $C-27$ positions and the $\beta, \beta$ ring juncture in the ring-A-fused compounds led to an enhancement in potency.

Thus, based on the SAR of withanolide analogs, the following correlations can be derived: (i) the presence of $\alpha, \beta$-unsaturation in ring $\mathrm{A}$ is critical for their biological activity, and the absence of a double bond in ring A reduces the activity profiles of the analogs [93]. (ii) Acylation on C-4, C-19, and C-27 results in increased activity against various cancer cell lines [71]. Withanolides isolated from $D$. wrightii, with oxygenation at the C-21 position, exhibited reduced anti-cancer potential compared to WA [83]. (iii) Withanolides having the $\beta$-hydroxyl group at $C$ - 4 and the $5 \beta, 6 \beta$-epoxy group in ring $B$ have been shown to be more potent compounds compared to those that are without these functionalities, and (iv) withanolides having the acetal group instead of the hydroxyl group at the C-18 position prove to be the more active compounds as these compounds have high lipophilicity [105].

Most of the WA modifications have been made through the ester bond at the C-4 and C-27 positions. Although many of these derivatives have been found significantly more potent than WA, the ester bonds are relatively unstable and can efficiently cleave in the body, releasing WA. The stability of the analogs can be increased via modification through the amide or triazole linkage. However, this would be challenging, synthetically starting with WA or other withanolide structures. Further, rational modifications of natural withanolides could provide safe and more target-specific compounds for individual diseases. Most of the structural modifications reported thus far are performed starting from withanolides, mostly from WA. This limits the diverse nature of compounds that can be generated. Although these modifications have already led to the discovery of several potent analogs, such structures can be better diversified to achieve potency and specificity towards particular molecular targets by developing synthetic techniques that could include the construction of a steroid skeleton. However, the challenge is to perform multi-step stereocontrolled syntheses of withanolide scaffolds to prepare rationally designed analogs that may not be accomplished by starting from withanolide structures. The synthesis of withaferin A, 
although multi-step and cumbersome, has been reported [152] and can be exploited as such or with improvements to generate more diverse novel analogs.

Apart from synthetic challenges, another hurdle in identifying potentially translational natural and synthetic withanolides, which have been shown to have varying degrees of activity against different cancer cell lines, is the lack of detailed studies on their efficacy and toxicity. Most of the studies report only in vitro cell viability data against different cancer cell lines, and many of them are not even compared against normal cells. In addition, studies are independently conducted in different labs using different assays, making it challenging to correlate which compounds would be the best for future development. Future studies could identify the top 20-25 most potent compounds, as reported, which can be compared under similar assay conditions and cancer cell lines and against normal cell lines to identify the best of the lot, with a high therapeutic index that could be studied in further pre-clinical in vivo models and, if found worthy, could eventually be developed clinically or serve as lead compounds for further optimization. Prioritizing promising synthetic analogs is also essential to reduce our dependence on natural sources, the production of which can be hampered in the future due to several factors, including extreme weather conditions, batch-to-batch consistency due to both the climate and the soil conditions, and lack of enough space for production due to the increasing world population.

Plants sources of withanolides, particularly the ancient medicinal herb Ashwagandha, have been traditionally used for several maladies. Although the anti-cancer properties of withanolides are well documented, there is also evidence, although insufficient, that Ashwagandha can reduce cholesterol levels, blood sugar levels, anxiety, and stress; improve fertility and testosterone in men, sperm quality, brain function, and sleep quality; and help fight depression and treat hypothyroidism. This information provides ample opportunity to test both natural and synthetically modified withanolides against such health conditions.

In summary, naturally occurring withanolides have shown great promise as pleiotropic therapeutic compounds in both in vitro and in vivo models and make valuable lead molecules for developing more potent and target-specific drug-like compounds. The derivatives developed and studied so far indicate that appropriately designed WA analogs could lead to promising drug candidates for various diseases, particularly cancer, in the near future and thus warrant further development.

Author Contributions: Conceptualization, A.K.S. and A.S.; Formal Analysis, A.S., A.R. and A.K.S.; Data Curation, A.S. and A.R.; Writing-Original Draft Preparation, A.S., A.R. and A.K.S.; WritingReview \& Editing, A.S., A.R., S.A., C.D. and A.K.S.; Visualization, A.S, A.R., S.A., C.D. and A.K.S.; Supervision, A.K.S. and C.D.; Project Administration, A.K.S.; Funding Acquisition, C.D. and A.K.S. All authors have read and agreed to the published version of the manuscript.

Funding: We acknowledge support from the NIH/NCI-1R01CA185972 to C.D. and A.K.S.

Institutional Review Board Statement: Not applicable.

Informed Consent Statement: Not applicable.

Data Availability Statement: Not applicable.

Acknowledgments: We thank the Department of Pharmacology, Penn State College of Medicine, and Penn State Cancer Institute for financial support.

Conflicts of Interest: The authors declare that they have no known competing financial interests or personal relationships that could have influenced the work reported in this paper.

\section{Abbreviations}

WA, withaferin A; WN, withanolids; MAPK, mitogen-activated protein kinase; NF- $\mathrm{B}$, nuclear factor 'kappa-light-chain-enhancer' of activated B-cell; Bcl-2, B-cell lymphoma-2; $\mathrm{GI}_{50}$, concentration for $50 \%$ of maximal inhibition of cell proliferation; 5-FU, 5-flourouracil; $\mathrm{IC}_{50}$, concentration of a drug that is required for $50 \%$ inhibition; ROS, reactive oxygen species; ERK, extracellular signalregulated kinase; JNK, c-Jun $\mathrm{N}$-terminal kinases; $\mathrm{NO}$, nitric oxide; $\mathrm{PI} 3 \mathrm{~K}$, phosphatidylinositol 3-kinase; 
mTORC, mammalian target of rapamycin complex; SAR, structure-activity relationship; NMR, nuclear magnetic resonance; TNF $\alpha$, tumor necrosis factor $\alpha$; DMSO, dimethyl sulfoxide; DMAP, 4dimethylaminopyridine; STATS, signal transducer and activator of transcription proteins; JAK, Janus kinases; COX-2, cyclooxygenase-2; fMLF/CB, N-formyl-methionyl-leucylphenylalanine/cytochalasin B; PDGF, platelet-derived growth factor; EGF, epidermal growth factor; HSP90, heat shock protein 90.

\section{References}

1. Newman, D.J.; Cragg, G.M. Natural Products as Sources of New Drugs over the Nearly Four Decades from 01/1981 to 09/2019. J. Nat. Prod. 2020, 83, 770-803. [CrossRef] [PubMed]

2. Cragg, G.M.; Grothaus, P.G.; Newman, D.J. New Horizons for Old Drugs and Drug Leads. J. Nat. Prod. 2014, 77, 703-723. [CrossRef] [PubMed]

3. Newman, D.J.; Cragg, G.M. Natural Products as Sources of New Drugs from 1981 to 2014. J. Nat. Prod. 2016, 79, 629-661. [CrossRef] [PubMed]

4. $\quad$ Barreca, M.; Spanò, V.; Montalbano, A.; Cueto, M.; Díaz Marrero, A.R.; Deniz, I.; Erdoğan, A.; Lukić Bilela, L.; Moulin, C.; Taffin-de-Givenchy, E. Marine anticancer agents: An overview with a particular focus on their chemical classes. Mar. Drugs 2020, 18, 619. [CrossRef]

5. Cragg, G.M.; Newman, D.J. Natural products: A continuing source of novel drug leads. Biochim. Biophys. Acta 2013, 1830, 3670-3695. [CrossRef]

6. Tripathi, N.; Shrivastava, D.; Ahmad Mir, B.; Kumar, S.; Govil, S.; Vahedi, M.; Bisen, P.S. Metabolomic and biotechnological approaches to determine therapeutic potential of Withania somnifera (L.) Dunal: A review. Phytomedicine 2018, 50, 127-136. [CrossRef]

7. Vanden Berghe, W.; Sabbe, L.; Kaileh, M.; Haegeman, G.; Heyninck, K. Molecular insight in the multifunctional activities of Withaferin A. Biochem. Pharmacol. 2012, 84, 1282-1291. [CrossRef]

8. Chen, L.X.; He, H.; Qiu, F. Natural withanolides: An overview. Nat. Prod. Rep. 2011, 28, 705-740. [CrossRef]

9. Hassannia, B.; Logie, E.; Vandenabeele, P.; Vanden Berghe, T.; Vanden Berghe, W. Withaferin A: From ayurvedic folk medicine to preclinical anti-cancer drug. Biochem. Pharmacol. 2020, 173, 113602. [CrossRef]

10. Jayaprakasam, B.; Zhang, Y.; Seeram, N.P.; Nair, M.G. Growth inhibition of human tumor cell lines by withanolides from Withania somnifera leaves. Life Sci. 2003, 74, 125-132. [CrossRef]

11. Ma, L.; Gan, X.-W.; He, Q.-P.; Bai, H.-Y.; Arfan, M.; Lou, F.-C.; Hu, L.-H. Cytotoxic Withaphysalins from Physalis minima. Helv. Chim. Acta 2007, 90, 1406-1419. [CrossRef]

12. Xu, X.-M.; Guan, Y.-Z.; Shan, S.-M.; Luo, J.-G.; Kong, L.-Y. Withaphysalin-type withanolides from Physalis minima. Phytochem. Lett. 2016, 15, 1-6. [CrossRef]

13. Zhang, H.; Cao, C.M.; Gallagher, R.J.; Day, V.W.; Kindscher, K.; Timmermann, B.N. Withanolides from Physalis coztomatl. Phytochemistry 2015, 109, 147-153. [CrossRef] [PubMed]

14. Abou-Douh, A.M. New withanolides and other constituents from the fruit of Withania somnifera. Arch. Pharm. 2002, 335, 267-276. [CrossRef]

15. Zhao, J.; Nakamura, N.; Hattori, M.; Kuboyama, T.; Tohda, C.; Komatsu, K. Withanolide derivatives from the roots of Withania somnifera and their neurite outgrowth activities. Chem. Pharm. Bull. 2002, 50, 760-765. [CrossRef]

16. Ding, H.; Hu, Z.; Yu, L.; Ma, Z.; Ma, X.; Chen, Z.; Wang, D.; Zhao, X. Induction of quinone reductase (QR) by withanolides isolated from Physalis angulata L. var. villosa Bonati (Solanaceae). Steroids 2014, 86, 32-38. [CrossRef]

17. Ji, L.; Yuan, Y.; Ma, Z.; Chen, Z.; Gan, L.; Ma, X.; Huang, D. Induction of quinone reductase (QR) by withanolides isolated from Physalis pubescens L. (Solanaceae). Steroids 2013, 78, 860-865. [CrossRef]

18. Misico, R.I.; Song, L.L.; Veleiro, A.S.; Cirigliano, A.M.; Tettamanzi, M.C.; Burton, G.; Bonetto, G.M.; Nicotra, V.E.; Silva, G.L.; Gil, R.R.; et al. Induction of quinone reductase by withanolides. J. Nat. Prod. 2002, 65, 677-680. [CrossRef]

19. Singh, N.; Bhalla, M.; de Jager, P.; Gilca, M. An overview on ashwagandha: A Rasayana (Rejuvenator) of Ayurveda. Afr. J. Tradit. Complement. Altern. Med. 2011, 8. [CrossRef]

20. Saggam, A.; Tillu, G.; Dixit, S.; Chavan-Gautam, P.; Borse, S.; Joshi, K.; Patwardhan, B. Withania somnifera (L.) Dunal: A potential therapeutic adjuvant in cancer. J. Ethnopharmacol. 2020, 255, 112759. [CrossRef]

21. Bhattacharya, S.K.; Goel, R.K.; Kaur, R.; Ghosal, S. Anti-stress activity of sitoindosides VII and VIII, new acylsterylglucosides from Withania somnifera. Phytother. Res. 1987, 1, 32-37. [CrossRef]

22. Khan, Z.A.; Ghosh, A.R. Possible nitric oxide modulation in protective effects of withaferin A against stress induced neurobehavioural changes. J. Med. Plant Res. 2010, 4, 490-495. [CrossRef]

23. Maitra, R.; Porter, M.A.; Huang, S.; Gilmour, B.P. Inhibition of NFkB by the natural product Withaferin A in cellular models of Cystic Fibrosis inflammation. J. Inflamm. 2009, 6, 1-5. [CrossRef] [PubMed]

24. Rasool, M.; Chandal, S.; Sabina, E.P. Inhibition of monosodium urate crystal-induced inflammation by withaferin A. J. Pharm. Pharm. Sci. 2008, 11, 46-55. [CrossRef] [PubMed] 
25. Lee, W.; Kim, T.H.; Ku, S.-K.; Min, K.-j.; Lee, H.-S.; Kwon, T.K.; Bae, J.-S. Barrier protective effects of withaferin A in HMGB1induced inflammatory responses in both cellular and animal models. Toxicol. Appl. Pharmacol. 2012, 262, 91-98. [CrossRef] [PubMed]

26. Heyninck, K.; Lahtela-Kakkonen, M.; Van der Veken, P.; Haegeman, G.; Berghe, W.V. Withaferin A inhibits NF-kappaB activation by targeting cysteine 179 in IKK $\beta$. Biochem. Pharmacol. 2014, 91, 501-509. [CrossRef] [PubMed]

27. Tiruveedi, V.L.; Bale, S.; Khurana, A.; Godugu, C. Withaferin A, a novel compound of Indian ginseng (Withania somnifera), ameliorates $C$ erulein-induced acute pancreatitis: Possible role of oxidative stress and inflammation. Phytother. Res. 2018, 32, 2586-2596. [CrossRef]

28. Bhattacharya, S.K.; Satyan, K.S.; Ghosal, S. Antioxidant activity of glycowithanolides from Withania somnifera. Indian J. Exp. Biol. 1997, 35, 236-239.

29. Yan, Z.; Guo, R.; Gan, L.; Lau, W.B.; Cao, X.; Zhao, J.; Ma, X.; Christopher, T.A.; Lopez, B.L.; Wang, Y. Withaferin A inhibits apoptosis via activated Akt-mediated inhibition of oxidative stress. Life Sci. 2018, 211, 91-101. [CrossRef]

30. Banu, M.R.; Ibrahim, M.; Prabu, K.; Rajasankar, S. Effect of Withaferin-A on aging induced behavioral and non-enzymatic antioxidant impairment in Wistar albino rat. Drug Invent. Today 2020, 13, 84-89.

31. Bhattacharya, S.; Bhattacharya, A.; Sairam, K.; Ghosal, S. Anxiolytic-antidepressant activity of Withania somnifera glycowithanolides: An experimental study. Phytomedicine 2000, 7, 463-469. [CrossRef]

32. Bharathi, P.; Seshayamma, V.; Jagannadharao, G.H.; Sivakumar, N. Evaluation of antidepressant activity of aqueous extract of Withania somnifera [Aswagandha] roots in albino mice. IOSR J. Pharm. Biol. Sci. 2015, 10, 27-29.

33. Bale, S.; Venkatesh, P.; Sunkoju, M.; Godugu, C. An adaptogen: Withaferin A ameliorates in vitro and in vivo pulmonary fibrosis by modulating the interplay of fibrotic, matricelluar proteins, and cytokines. Front. Pharmacol. 2018, 9, 248. [CrossRef] [PubMed]

34. Singh, N.; Nath, R.; Lata, A.; Singh, S.; Kohli, R.; Bhargava, K. Withania somnifera (ashwagandha), a rejuvenating herbal drug which enhances survival during stress (an adaptogen). Int. J. Crude Drug Res. 1982, 20, 29-35. [CrossRef]

35. Bhattacharya, S.; Muruganandam, A. Adaptogenic activity of Withania somnifera: An experimental study using a rat model of chronic stress. Pharmacol. Biochem. Behav. 2003, 75, 547-555. [CrossRef]

36. Mácsai, L.; Datki, Z.L.; Csupor, D.; Horváth, A.; Zomborszki, Z.P. Biological activities of four adaptogenic plant extracts and their active substances on a rotifer model. Evid. Based Complement. Altern. Med. 2018, 2018, 3690683. [CrossRef]

37. Bhat, W.W.; Lattoo, S.K.; Razdan, S.; Dhar, N.; Rana, S.; Dhar, R.S.; Khan, S.; Vishwakarma, R.A. Molecular cloning, bacterial expression and promoter analysis of squalene synthase from Withania somnifera (L.) Dunal. Gene 2012, 499, 25-36. [CrossRef]

38. Sari, A.N.; Bhargava, P.; Dhanjal, J.K.; Putri, J.F.; Radhakrishnan, N.; Shefrin, S.; Ishida, Y.; Terao, K.; Sundar, D.; Kaul, S.C. Combination of Withaferin-A and CAPE Provides Superior Anticancer Potency: Bioinformatics and Experimental Evidence to Their Molecular Targets and Mechanism of Action. Cancers 2020, 12, 1160. [CrossRef]

39. Sivasankarapillai, V.S.; Nair, R.M.K.; Rahdar, A.; Bungau, S.; Zaha, D.C.; Aleya, L.; Tit, D.M. Overview of the anticancer activity of withaferin A, an active constituent of the Indian ginseng Withania somnifera. Environ. Sci. Pollut. Res. Int. 2020, 27, 26025-26035. [CrossRef]

40. Sehrawat, A.; Samanta, S.K.; Kim, S.-H.; Hahm, E.-R.; Singh, S.V. Scientific Evidence for Anticancer Effects of Withania somnifera and Its Primary Bioactive Component Withaferin A. In Science of Ashwagandha: Preventive and Therapeutic Potentials; Springer: Cham, Switzerland, 2017; pp. 175-196.

41. Rai, M.; Jogee, P.S.; Agarkar, G.; Santos, C.A.d. Anticancer activities of Withania somnifera: Current research, formulations, and future perspectives. Pharm. Biol. 2016, 54, 189-197. [CrossRef]

42. Liu, X.; Li, Y.; Ma, Q.; Wang, Y.; Song, A.L. Withaferin-A Inhibits Growth of Drug-Resistant Breast Carcinoma by Inducing Apoptosis and Autophagy, Endogenous Reactive Oxygen Species (ROS) Production, and Inhibition of Cell Migration and Nuclear Factor kappa B (Nf-kB)/Mammalian Target of Rapamycin (m-TOR) Signalling Pathway. Med. Sci. Monit. 2019, $25,6855$. [CrossRef] [PubMed]

43. Yin, X.; Yang, G.; Ma, D.; Su, Z. Inhibition of cancer cell growth in cisplatin-resistant human oral cancer cells by withaferin-A is mediated via both apoptosis and autophagic cell death, endogenous ROS production, G2/M phase cell cycle arrest and by targeting MAPK/RAS/RAF signalling pathway. J. BUON 2020, 25, 332-337. [PubMed]

44. Umarani, B.; Saravanan, K. Anticancer agents from some known plants: A review. Infokara Res. 2020, 9, 582-603.

45. Katiyar, S.P.; Malik, V.; Kumari, A.; Sundar, D. Computational Methods to Understand the Anticancer Mechanism of Withanolides. In Science of Ashwagandha: Preventive and Therapeutic Potentials; Springer: Cham, Switzerland, 2017; pp. 263-280.

46. Llanos, G.G.; Araujo, L.M.; Jimenez, I.A.; Moujir, L.M.; Rodriguez, J.; Jimenez, C.; Bazzocchi, I.L. Structure-based design, synthesis, and biological evaluation of withaferin A-analogues as potent apoptotic inducers. Eur. J. Med. Chem. 2017, 140, 52-64. [CrossRef]

47. Samant, R.R.; Samant, R.S. Choking cancer: Developing a pathway of Withaferin A for the prevention of angiogenesis. Mol. Cell. Biol. 2020, 80. [CrossRef]

48. Munir, S.; Shah, A.A.; Shahid, M.; Ahmed, M.S.; Shahid, A.; Rajoka, M.S.; Akash, M.S.; Akram, M.; Khurshid, M. Anti-angiogenesis potential of phytochemicals for the therapeutic management of tumors. Curr. Pharm. Des. 2020, 26, 265-278. [CrossRef] [PubMed]

49. Misra, L.; Lal, P.; Chaurasia, N.D.; Sangwan, R.S.; Sinha, S.; Tuli, R. Selective reactivity of 2-mercaptoethanol with 5beta,6betaepoxide in steroids from Withania somnifera. Steroids 2008, 73, 245-251. [CrossRef]

50. Aggarwal, B.B.; Vijayalekshmi, R.; Sung, B. Targeting inflammatory pathways for prevention and therapy of cancer: Short-term friend, long-term foe. Clin. Cancer. Res. 2009, 15, 425-430. [CrossRef] 
51. Tyagi, A.; Chandrasekaran, B.; Kolluru, V.; Baby, B.V.; Sripathi, C.A.; Ankem, M.K.; Ramisetti, S.R.; Chirasani, V.R.; Dokholyan, N.V.; Sharma, A.K.; et al. ASR490, a Small Molecule, Overrides Aberrant Expression of Notch1 in colorectal cancer. Mol. Cancer Ther. 2020, 19, 2422-2431. [CrossRef]

52. Siegel, R.L.; Miller, K.D.; Jemal, A. Cancer statistics, 2019. CA Cancer J. Clin. 2019, 69, 7-34. [CrossRef]

53. Ur Rashid, H.; Xu, Y.; Muhammad, Y.; Wang, L.; Jiang, J. Research advances on anticancer activities of matrine and its derivatives: An updated overview. Eur. J. Med. Chem. 2019, 161, 205-238. [CrossRef] [PubMed]

54. Hanahan, D.; Weinberg, R.A. Hallmarks of cancer: The next generation. Cell 2011, 144, 646-674. [CrossRef] [PubMed]

55. Hainaut, P.; Plymoth, A. Targeting the hallmarks of cancer: Towards a rational approach to next-generation cancer therapy. Curr. Opin. Oncol. 2013, 25, 50-51. [CrossRef] [PubMed]

56. Wan, Y.; Li, Y.; Yan, C.; Yan, M.; Tang, Z. Indole: A privileged scaffold for the design of anti-cancer agents. Eur. J. Med. Chem. 2019, 183, 111691. [CrossRef]

57. Jiao, Q.; Bi, L.; Ren, Y.; Song, S.; Wang, Q.; Wang, Y.-s. Advances in studies of tyrosine kinase inhibitors and their acquired resistance. Mol. Cancer 2018, 17, 1-12. [CrossRef]

58. Liu, P.; Zhao, L.; Loos, F.; Iribarren, K.; Kepp, O.; Kroemer, G. Epigenetic anticancer agents cause HMGB1 release in vivo. Oncoimmunology 2018, 7, e1431090. [CrossRef]

59. Huang, H.-L.; Chao, M.-W.; Li, Y.-C.; Chang, L.-H.; Chen, C.-H.; Chen, M.-C.; Cheng, C.-C.; Liou, J.-P.; Teng, C.-M.; Pan, S.-L. MPT0G066, a novel anti-mitotic drug, induces JNK-independent mitotic arrest, JNK-mediated apoptosis and potentiates antineoplastic effect of cisplatin in ovarian cancer. Sci. Rep. 2016, 6, 1-11. [CrossRef]

60. Qian-Qian, X.; Kui-Wu, W. Natural Bioactive New Withanolides. Mini Rev. Med. Chem. 2020, 20, 1101-1117. [CrossRef]

61. Zhang, W.N.; Tong, W.Y. Chemical constituents and biological activities of plants from the genus Physalis. Chem. Biodivers. 2016, 13, 48-65. [CrossRef]

62. Jin, Z.; Mashuta, M.S.; Stolowich, N.J.; Vaisberg, A.J.; Stivers, N.S.; Bates, P.J.; Lewis, W.H.; Hammond, G.B. Physangulidines A, B, and C: Three New Antiproliferative Withanolides from Physalis angulata L. Org. Lett. 2012, 14, 1230-1233. [CrossRef]

63. Ma, T.; Zhang, W.-N.; Yang, L.; Zhang, C.; Lin, R.; Shan, S.-M.; Zhu, M.-D.; Luo, J.-G.; Kong, L.-Y. Cytotoxic withanolides from Physalis angulata var. villosa and the apoptosis-inducing effect via ROS generation and the activation of MAPK in human osteosarcoma cells. RSC Adv. 2016, 6, 53089-53100. [CrossRef]

64. Sun, C.-P.; Qiu, C.-Y.; Yuan, T.; Nie, X.-F.; Sun, H.-X.; Zhang, Q.; Li, H.-X.; Ding, L.-Q.; Zhao, F.; Chen, L.-X. Antiproliferative and anti-inflammatory withanolides from Physalis angulata. J. Nat. Prod. 2016, 79, 1586-1597. [CrossRef] [PubMed]

65. Meng, Q.; Fan, J.; Liu, Z.; Li, X.; Zhang, F.; Zhang, Y.; Sun, Y.; Li, L.; Liu, X.; Hua, E. Cytotoxic Withanolides from the Whole Herb of Physalis angulata L. Molecules 2019, 24, 1608. [CrossRef] [PubMed]

66. Li, A.-L.; Chen, B.-J.; Li, G.-H.; Zhou, M.-X.; Li, Y.-R.; Ren, D.-M.; Lou, H.-X.; Wang, X.-N.; Shen, T. Physalis alkekengi L. var. franchetii (Mast.) Makino: An ethnomedical, phytochemical and pharmacological review. J. Ethnopharmacol. 2018, 210, 260-274. [CrossRef]

67. Bahmani, M.; Rafieian-Kopaei, M.; Naghdi, N.; Nejad, A.S.M.; Afsordeh, O. Physalis alkekengi: A review of its therapeutic effects. J. Chem. Pharm. Res. 2016, 9, 1472-1485.

68. Zhang, Q.; Hu, X.-F.; Xin, M.-m.; Liu, H.-B.; Sun, L.-J.; Morris-Natschke, S.L.; Chen, Y.; Lee, K.-H. Antidiabetic potential of the ethyl acetate extract of Physalis alkekengi and chemical constituents identified by HPLC-ESI-QTOF-MS. J. Ethnopharm. 2018, 225, 202-210. [CrossRef]

69. Zhang, C.-Y.; Luo, J.-G.; Liu, R.-H.; Lin, R.; Yang, M.-H.; Kong, L.-Y. 1H NMR spectroscopy-guided isolation of new sucrose esters from Physalis alkekengi var. franchetii and their antibacterial activity. Fitoterapia 2016, 114, 138-143. [CrossRef]

70. Sun, Y.; Guo, T.; Zhang, F.-b.; Wang, Y.-n.; Liu, Z.; Guo, S.; Li, L. Isolation and characterization of cytotoxic withanolides from the calyx of Physalis alkekengi L. var franchetii. Bioorg. Chem. 2020, 96, 103614. [CrossRef]

71. Zhang, H.; Samadi, A.K.; Gallagher, R.J.; Araya, J.J.; Tong, X.; Day, V.W.; Cohen, M.S.; Kindscher, K.; Gollapudi, R.; Timmermann, B.N. Cytotoxic withanolide constituents of Physalis longifolia. J. Nat. Prod. 2011, 74, 2532-2544. [CrossRef]

72. Castetter, E.F.; Underhill, R.M. The Ethnobiology of the Papago Indians. Available online: https://digitalrepository.unm.edu/ unm_bulletin/25 (accessed on 19 December 2021).

73. Castetter, E.F.; Opler, M.E. The Use of Plants for Foods, Beverages and Narcotics. Available online: https://digitalrepository.unm edu/unm_bulletin (accessed on 19 December 2021).

74. Cao, C.M.; Wu, X.; Kindscher, K.; Xu, L.; Timmermann, B.N. Withanolides and Sucrose Esters from Physalis neomexicana. J. Nat. Prod. 2015, 78, 2488-2493. [CrossRef]

75. Xu, Y.-m.; Bunting, D.P.; Liu, M.X.; Bandaranayake, H.A.; Gunatilaka, A.L. 17ß-Hydroxy-18-acetoxywithanolides from aeroponically grown Physalis crassifolia and their potent and selective cytotoxicity for prostate cancer cells. J. Nat. Prod. 2016, 79, 821-830. [CrossRef] [PubMed]

76. Yang, M.; Chen, Z.; Li, X.; Xu, Q.; Yang, S. Chemical constituents in persistent calyx of Physalis pubescens (I). Chin. Tradit. Herb. Drug 2013, 44, 253-256. [CrossRef]

77. Xia, G.; Li, Y.; Sun, J.; Wang, L.; Tang, X.; Lin, B.; Kang, N.; Huang, J.; Chen, L.; Qiu, F. Withanolides from the stems and leaves of Physalis pubescens and their cytotoxic activity. Steroids 2016, 115, 136-146. [CrossRef] [PubMed]

78. Zhang, H.; Samadi, A.K.; Cohen, M.S.; Timmermann, B.N. Antiproliferative withanolides from the Solanaceae: A structureactivity study. Pure Appl. Chem. 2012, 84, 1353-1367. [CrossRef] 
79. LLanos, G.G.; Araujo, L.M.; Jiménez, I.A.; Moujir, L.M.; Vázquez, J.T.; Bazzocchi, I.L. Withanolides from Withania aristata and their cytotoxic activity. Steroids 2010, 75, 974-981. [CrossRef]

80. Xu, Y.-M.; Wijeratne, E.K.; Babyak, A.L.; Marks, H.R.; Brooks, A.D.; Tewary, P.; Xuan, L.-J.; Wang, W.-Q.; Sayers, T.J.; Gunatilaka, A.L. Withanolides from aeroponically grown Physalis peruviana and their selective cytotoxicity to prostate cancer and renal carcinoma cells. J. Nat. Prod. 2017, 80, 1981-1991. [CrossRef]

81. Vermillion, K.; Holguin, F.O.; Berhow, M.A.; Richins, R.D.; Redhouse, T.; O'Connell, M.A.; Posakony, J.; Mahajan, S.S.; Kelly, S.M.; Simon, J.A. Dinoxin B, a Withanolide from Datura inoxia Leaves with Specific Cytotoxic Activities. J. Nat. Prod. 2011, 74, $267-271$. [CrossRef]

82. Ma, L.; Xie, C.-M.; Li, J.; Lou, F.-C.; Hu, L.-H. Daturametelins H, I, and J: Three New Withanolide Glycosides from Datura metel L. Chem. Biodivers. 2006, 3, 180-186. [CrossRef]

83. Zhang, H.; Bazzill, J.; Gallagher, R.J.; Subramanian, C.; Grogan, P.T.; Day, V.W.; Kindscher, K.; Cohen, M.S.; Timmermann, B.N. Antiproliferative withanolides from Datura wrightii. J. Nat. Prod. 2013, 76, 445-449. [CrossRef]

84. Wang, X.Y.; He, J.; Bai, H.J.; Gao, P.Y.; Gan, H.; Yang, T.; Zhang, W.K.; Xu, J.K. Daturanolide A-C, Three New Withanolides from Datura metel L. and Their Cytotoxic Activities. Chem. Biodivers. 2019, 16, e1900004. [CrossRef]

85. Hassannia, B.; Wiernicki, B.; Ingold, I.; Qu, F.; Van Herck, S.; Tyurina, Y.Y.; Bayır, H.; Abhari, B.A.; Angeli, J.P.F.; Choi, S.M.; et al. Nano-targeted induction of dual ferroptotic mechanisms eradicates high-risk neuroblastoma. J. Clin. Investig. 2018, 128, 3341-3355. [CrossRef] [PubMed]

86. Ihsan ul, H.; Youn, U.J.; Chai, X.; Park, E.J.; Kondratyuk, T.P.; Simmons, C.J.; Borris, R.P.; Mirza, B.; Pezzuto, J.M.; Chang, L.C. Biologically active withanolides from Withania coagulans. J. Nat. Prod. 2013, 76, 22-28. [CrossRef] [PubMed]

87. Khan, M.I.; Maqsood, M.; Saeed, R.A.; Alam, A.; Sahar, A.; Kieliszek, M.; Miecznikowski, A.; Muzammil, H.S.; Aadil, R.M. Phytochemistry, Food Application, and Therapeutic Potential of the Medicinal Plant (Withania coagulans): A Review. Molecules 2021, 26, 6881. [CrossRef] [PubMed]

88. Hepper, F.N. Old World Withania (Solanaceae): A taxonomic review and key to the species. Loc. Cit 1991, $211-227$.

89. González, A.; Darias, V.; Martin, H.; Suarez, M. Cytostatic activity of natural withanolides from Spanish Withania. Fitoterapia 1982, 53, 85-88.

90. El Bouzidi, L.; Mahiou-Leddet, V.; Bun, S.-S.; Larhsini, M.; Abbad, A.; Markouk, M.; Fathi, M.; Boudon, M.; Ollivier, E.; Bekkouche, K. Cytotoxic withanolides from the leaves of Moroccan Withania frutescens. Pharm. Biol. 2013, 51, 1040-1046. [CrossRef] [PubMed]

91. Xu, Y.-m.; Marron, M.T.; Seddon, E.; McLaughlin, S.P.; Ray, D.T.; Whitesell, L.; Leslie Gunatilaka, A.A. 2,3-Dihydrowithaferin A-3 $\beta$-O-sulfate, a new potential prodrug of withaferin A from aeroponically grown Withania somnifera. Bioorg. Med. Chem. 2009, 17, 2210-2214. [CrossRef]

92. Kim, S.; Yu, J.S.; Lee, J.Y.; Choi, S.U.; Lee, J.; Kim, K.H. Cytotoxic withanolides from the roots of Indian Ginseng (Withania somnifera). J. Nat. Prod. 2019, 82, 765-773. [CrossRef]

93. Martin, F.W. Tropical Yams and Their Potential. Part 2. Dioscorea bulbifera; United States Department of Agriculture: Washington, DC, USA, 1974; 24p.

94. Kim, K.H.; Choi, S.U.; Choi, S.Z.; Son, M.W.; Lee, K.R. Withanolides from the Rhizomes of Dioscorea japonica and Their Cytotoxicity. J. Agric. Food Chem. 2011, 59, 6980-6984. [CrossRef]

95. Su, B.-N.; Park, E.J.; Nikolic, D.; Santarsiero, B.D.; Mesecar, A.D.; Vigo, J.S.; Graham, J.G.; Cabieses, F.; van Breemen, R.B.; Fong, H.H.S.; et al. Activity-Guided Isolation of Novel Norwithanolides from Deprea subtriflora with Potential Cancer Chemopreventive Activity. J. Org. Chem. 2003, 68, 2350-2361. [CrossRef]

96. Damu, A.G.; Kuo, P.-C.; Su, C.-R.; Kuo, T.-H.; Chen, T.-H.; Bastow, K.F.; Lee, K.-H.; Wu, T.-S. Isolation, Structures, and Structure-Cytotoxic Activity Relationships of Withanolides and Physalins from Physalis angulata. J. Nat. Prod. 2007, 70, 1146-1152. [CrossRef] [PubMed]

97. Huang, C.-Y.; Liaw, C.-C.; Chen, B.-W.; Chen, P.-C.; Su, J.-H.; Sung, P.-J.; Dai, C.-F.; Chiang, M.Y.; Sheu, J.-H. Withanolide-based steroids from the cultured soft coral Sinularia brassica. J. Nat. Prod. 2013, 76, 1902-1908. [CrossRef] [PubMed]

98. Liu, Z.-H.; Yan, H.; Si, Y.-A.; Ni, W.; Chen, Y.; Chen, C.-X.; He, L.; Zhang, Z.-Q.; Liu, H.-Y. Plantagiolides K-N, three new withanolides and one withanolide glucoside from Tacca plantaginea. Fitoterapia 2015, 105, 210-214. [CrossRef] [PubMed]

99. Batista, P.H.J.; de Lima, K.S.B.; Francisco das Chagas, L.P.; Tavares, J.L.; Daniel, E.d.A.; Costa-Lotufo, L.V.; Rocha, D.D.; Silveira, E.R.; Bezerra, A.M.E.; Canuto, K.M. Withanolides from leaves of cultivated Acnistus arborescens. Phytochemistry 2016, 130, 321-327. [CrossRef]

100. Hsieh, P.-W.; Huang, Z.-Y.; Chen, J.-H.; Chang, F.-R.; Wu, C.-C.; Yang, Y.-L.; Chiang, M.Y.; Yen, M.-H.; Chen, S.-L.; Yen, H.-F. Cytotoxic withanolides from Tubocapsicum anomalum. J. Nat. Prod. 2007, 70, 747-753. [CrossRef] [PubMed]

101. Wang, S.-B.; Zhu, D.-R.; Nie, B.; Li, J.; Zhang, Y.-J.; Kong, L.-Y.; Luo, J.-G. Cytotoxic withanolides from the aerial parts of Tubocapsicum anomalum. Bioorg. Chem. 2018, 81, 396-404. [CrossRef]

102. Lin, R.; Guan, Y.Z.; Li, R.J.; Xu, X.M.; Luo, J.G.; Kong, L.Y. 13, 14-seco-Withanolides from Physalis minima with Potential Anti-inflammatory Activity. Chem. Biodivers. 2016, 13, 884-890. [CrossRef]

103. Li, R.-J.; Gao, C.-Y.; Guo, C.; Zhou, M.-M.; Luo, J.; Kong, L.-Y. The Anti-inflammatory activities of two major withanolides from Physalis minima via acting on NF-kB, STAT3, and HO-1 in LPS-stimulated RAW264. 7 cells. Inflammation 2017, 40, 401-413. [CrossRef] 
104. Castro, S.n.J.; Casero, C.N.; Padrón, J.M.; Nicotra, V.E. Selective Antiproliferative Withanolides from Species in the Genera Eriolarynx and Deprea. J. Nat. Prod. 2019, 82, 1338-1344. [CrossRef]

105. Xu, Y.-M.; Liu, M.X.; Grunow, N.; Wijeratne, E.K.; Paine-Murrieta, G.; Felder, S.; Kris, R.M.; Gunatilaka, A.L. Discovery of potent $17 \beta$-hydroxywithanolides for castration-resistant prostate cancer by high-throughput screening of a natural products library for androgen-induced gene expression inhibitors. J. Med. Chem. 2015, 58, 6984-6993. [CrossRef]

106. Seligmann, B. Improved genomics and proteomics array technology. Am. Biotechnol. Lab. 2001, 19, 34.

107. Kris, R.M.; Felder, S.; Deyholos, M.; Lambert, G.M.; Hinton, J.; Botros, I.; Martel, R.; Seligmann, B.; Galbraith, D.W. Highthroughput, high-sensitivity analysis of gene expression in Arabidopsis. Plant Physiol. 2007, 144, 1256-1266. [CrossRef] [PubMed]

108. Henrich, C.; Brooks, A.; Erickson, K.; Thomas, C.; Bokesch, H.; Tewary, P.; Thompson, C.; Pompei, R.; Gustafson, K.; McMahon, J. Withanolide E sensitizes renal carcinoma cells to TRAIL-induced apoptosis by increasing cFLIP degradation. Cell Death Dis. 2015, 6, e1666. [CrossRef] [PubMed]

109. Fesik, S.W. Promoting apoptosis as a strategy for cancer drug discovery. Nat. Rev. Cancer 2005, 5, 876-885. [CrossRef]

110. Perestelo, N.R.; Llanos, G.G.; Reyes, C.P.; Amesty, A.; Sooda, K.; Afshinjavid, S.; Jiménez, I.A.; Javid, F.; Bazzocchi, I.L. Expanding the Chemical Space of Withaferin A by Incorporating Silicon To Improve Its Clinical Potential on Human Ovarian Carcinoma Cells. J. Med. Chem. 2019, 62, 4571-4585. [CrossRef]

111. Wijeratne, E.K.; Xu, Y.-M.; Scherz-Shouval, R.; Marron, M.T.; Rocha, D.D.; Liu, M.X.; Costa-Lotufo, L.V.; Santagata, S.; Lindquist, S.; Whitesell, L. Structure-activity relationships for withanolides as inducers of the cellular heat-shock response. J. Med. Chem. 2014, 57, 2851-2863. [CrossRef] [PubMed]

112. Tyagi, A.; Kolluru, V.; Chandrasekaran, B.; Saran, U.; Sharma, A.K.; Ankem, M.K.; Damodaran, C. ASR488, a novel small molecule, activates an mRNA binding protein, CPEB1, and inhibits the growth of bladder cancer. Oncol. Lett. 2020, 20, 850-860. [CrossRef]

113. Yousuf, S.K.; Majeed, R.; Ahmad, M.; lal Sangwan, P.; Purnima, B.; Saxsena, A.; Suri, K.; Mukherjee, D.; Taneja, S.C. Ring A structural modified derivatives of withaferin A and the evaluation of their cytotoxic potential. Steroids 2011, 76, 1213-1222. [CrossRef]

114. Motiwala, H.F.; Bazzill, J.; Samadi, A.; Zhang, H.; Timmermann, B.N.; Cohen, M.S.; Aubé, J. Synthesis and cytotoxicity of semisynthetic withalongolide A analogues. ACS Med. Chem. Lett. 2013, 4, 1069-1073. [CrossRef] [PubMed]

115. Fulda, S. Resveratrol and derivatives for the prevention and treatment of cancer. Drug Discov. Today 2010, 15, 757-765. [CrossRef]

116. Isbrucker, R.A.; Gunasekera, S.P.; Longley, R.E. Structure-activity relationship studies of discodermolide and its semisynthetic acetylated analogs on microtubule function and cytotoxicity. Cancer Chemother. Pharmacol. 2001, 48, 29-36. [CrossRef] [PubMed]

117. DeLorbe, J.E.; Clements, J.H.; Whiddon, B.B.; Martin, S.F. Thermodynamic and structural effects of macrocyclic constraints in protein- ligand interactions. J. Phys. Chem. B 2010, 1, 448-452. [CrossRef] [PubMed]

118. Meyer, F.-M.; Collins, J.C.; Borin, B.; Bradow, J.; Liras, S.; Limberakis, C.; Mathiowetz, A.M.; Philippe, L.; Price, D.; Song, K. Biaryl-bridged macrocyclic peptides: Conformational constraint via carbogenic fusion of natural amino acid side chains. J. Org. Chem. 2012, 77, 3099-3114. [CrossRef] [PubMed]

119. Rasool, F.; Nayak, D.; Katoch, A.; Faheem, M.M.; Yousuf, S.K.; Hussain, N.; Belawal, C.; Satti, N.; Goswami, A.; Mukherjee, $\mathrm{D}$. Regiospecific synthesis of ring a fused withaferin a isoxazoline analogues: Induction of premature senescence by $\mathrm{W}-2 \mathrm{~b}$ in proliferating cancer cells. Sci. Rep. 2017, 7, 1-18. [CrossRef]

120. Tangallapally, R.P.; Sun, D.; Budha, N.; Lee, R.E.; Lenaerts, A.J.; Meibohm, B.; Lee, R.E. Discovery of novel isoxazolines as anti-tuberculosis agents. Bioorg. Med. Chem. Lett. 2007, 17, 6638-6642. [CrossRef]

121. Ferrero-Miliani, L.; Nielsen, O.; Andersen, P.; Girardin, S. Chronic inflammation: Importance of NOD2 and NALP3 in interleukin$1 \beta$ generation. Clin. Exp. Immunol. 2007, 147, 227-235. [CrossRef]

122. Calder, P.C. $\mathrm{n}-3$ polyunsaturated fatty acids, inflammation, and inflammatory diseases. Am. J. Clin. Nutr. 2006, 83, 1505S-1519S. [CrossRef]

123. Ran, S.; Montgomery, K.E. Macrophage-mediated lymphangiogenesis: The emerging role of macrophages as lymphatic endothelial progenitors. Cancers 2012, 4, 618-657. [CrossRef]

124. Lawrence, T.; Willoughby, D.A.; Gilroy, D.W. Anti-inflammatory lipid mediators and insights into the resolution of inflammation. Nat. Rev. Immunol. 2002, 2, 787-795. [CrossRef]

125. Ariel, A.; Serhan, C.N. Resolvins and protectins in the termination program of acute inflammation. Trends Immunol. 2007, 28, 176-183. [CrossRef]

126. Clark, R.; Kupper, T. Old Meets New: The Interaction Between Innate and Adaptive Immunity. J. Investig. Dermatol. 2005, 125, 629-637. [CrossRef] [PubMed]

127. Chao, C.-H.; Chou, K.-J.; Wen, Z.-H.; Wang, G.-H.; Wu, Y.-C.; Dai, C.-F.; Sheu, J.-H. Paraminabeolides A- F, cytotoxic and anti-inflammatory marine withanolides from the soft coral Paraminabea acronocephala. J. Nat. Prod. 2011, 74, $1132-1141$. [CrossRef] [PubMed]

128. Kuang, H.-X.; Yang, B.-Y.; Xia, Y.-G.; Wang, Q.-H. Two new withanolide lactones from flos daturae. Molecules 2011, 16, 5833-5839. [CrossRef] [PubMed]

129. Wang, Q.; Xiao, H.; Yang, B.; Yao, F.; Kuang, H. Studies on pharmacological actions of the effective parts for psoriasis in Flos Daturae (I). Chin. J. Exp. Trad. Med. Formulae 2008, 14, 48-51. 
130. Yang, B.-Y.; Guo, R.; Li, T.; Liu, Y.; Wang, C.-F.; Shu, Z.-P.; Wang, Z.-B.; Zhang, J.; Xia, Y.-G.; Jiang, H. Five withanolides from the leaves of Datura metel L. and their inhibitory effects on nitric oxide production. Molecules 2014, 19, 4548-4559. [CrossRef] [PubMed]

131. Lai, P.K.K.; Chan, J.Y.W.; Wu, S.B.; Cheng, L.; Ho, G.K.W.; Lau, C.P.; Kennelly, E.J.; Leung, P.C.; Fung, K.P.; Lau, C.B.S. Antiinflammatory Activities of an Active Fraction Isolated from the root of Astragalus membranaceus in RAW 264.7 Macrophages. Phytother. Res. 2014, 28, 395-404. [CrossRef]

132. Sahai, M.; Kirson, I. Withaphysalin D, a new withaphysalin from Physalis minima Linn. var. indica. J. Nat. Prod. 1984, 47, 527-529. [CrossRef]

133. Sen, G.; Pathak, H. Physalin L, a 13, 14-seco-16, 24 cyclosteroid from Physalis minima. Phytochemistry 1995, 39, 1245-1246. [CrossRef]

134. Ji, L.; Yuan, Y.; Luo, L.; Chen, Z.; Ma, X.; Ma, Z.; Cheng, L. Physalins with anti-inflammatory activity are present in Physalis alkekengi var. franchetii and can function as Michael reaction acceptors. Steroids 2012, 77, 441-447. [CrossRef]

135. Sang-ngern, M.; Youn, U.J.; Park, E.-J.; Kondratyuk, T.P.; Simmons, C.J.; Wall, M.M.; Ruf, M.; Lorch, S.E.; Leong, E.; Pezzuto, J.M. Withanolides derived from Physalis peruviana (Poha) with potential anti-inflammatory activity. Bioorg. Med. Chem. Lett. 2016, 26, 2755-2759. [CrossRef]

136. Huang, C.-Y.; Ahmed, A.F.; Su, J.-H.; Sung, P.-J.; Hwang, T.-L.; Chiang, P.-L.; Dai, C.-F.; Liaw, C.-C.; Sheu, J.-H. Bioactive new withanolides from the cultured soft coral Sinularia brassica. Bioorg. Med. Chem. Lett. 2017, 27, 3267-3271. [CrossRef] [PubMed]

137. Zhang, P.; Wu, Y.-L.; Niu, Y.-X.; Li, Z.-L.; Zhu, L.-H.; Li, H.; Chen, L.-X. Withanolides and aromatic glycosides isolated from Nicandra physaloides and their anti-inflammatory activity. Fitoterapia 2018, 131, 260-264. [CrossRef] [PubMed]

138. Tsarong, T.J. Tibetan Medicinal Plants; Tibetan Medical Publications: Tibet, China, 1994.

139. Xie, Y.; Yu, L.; Huang, Q.; Li, S. Seed germination characteristics of Nicandra physaloides. Seed Sci. Technol. 2009, $29,839-841$. [CrossRef]

140. Mareggiani, G.; Picollo, M.; Zerba, E.; Burton, G.; Tettamanzi, M.; Benedetti-Doctorovich, M.; Veleiro, A. Antifeedant Activity of Withanolides from Salpichroa o riganifolia on Musca d omestica. J. Nat. Prod. 2000, 63, 1113-1116. [CrossRef]

141. Vaccarini, C.E.; Bonetto, G.M. Antifeedant activity evaluation of withanolides from Jaborosa integrifolia. Molecules 2000, 5, 422-423. [CrossRef]

142. Yang, B.Y.; Liu, Y.; Jiang, H.B.; Xu, Z.P.; Guo, R.; Wang, R.; Li, X.M.; Kuang, H.X. Phenylpropanoids from the fruits of Nicandra physaloides and their anti-inflammatory activities. Nat. Prod. Res. 2017, 31, 2634-2640. [CrossRef]

143. Reyes-Reyes, E.M.; Jin, Z.; Vaisberg, A.J.; Hammond, G.B.; Bates, P.J. Physangulidine A, a withanolide from Physalis angulata, perturbs the cell cycle and induces cell death by apoptosis in prostate cancer cells. J. Nat. Prod. 2013, 76, 2-7. [CrossRef]

144. Yang, B.-Y.; Guo, R.; Li, T.; Wu, J.-J.; Zhang, J.; Liu, Y.; Wang, Q.-H.; Kuang, H.-X. New anti-inflammatory withanolides from the leaves of Datura metel L. Steroids 2014, 87, 26-34. [CrossRef]

145. Lin, Y.-C.; Chao, C.-H.; Ahmed, A.F.; Chen, Y.-Y.; Hwang, T.-L.; Liu, H.-Y.; Sheu, J.-H. Withanolides and 26-Hydroxylated Derivatives with Anti-Inflammatory Property from Solanum Capsicoide. Bull. Chem. Soc. Jpn. 2019, 92, 336-343. [CrossRef]

146. Tan, J.; Liu, Y.; Cheng, Y.; Sun, Y.; Pan, J.; Guan, W.; Li, X.; Huang, J.; Jiang, P.; Guo, S. New withanolides with anti-inflammatory activity from the leaves of Datura metel L. Bioorg. Chem. 2020, 95, 103541. [CrossRef]

147. Gutierrez Nicolas, F.; Reyes, G.; Audisio, M.C.; Uriburu, M.L.; Leiva Gonzalez, S.; Barboza, G.E.; Nicotra, V.E. Withanolides with Antibacterial Activity from Nicandra john-tyleriana. J. Nat. Prod. 2015, 78, 250-257. [CrossRef] [PubMed]

148. Leiva, S.; Pereyra, V. Nicandra john-tyleriana (Solanaceae) una nueva especie del Norte del Perú. Arnaldoa 2007, $14,45-52$.

149. Leiva, S. Nicandra yacheriana (Solanaceae) una nueva especie del Sur del Perú. Arnaldoa 2010, 17, 25-31.

150. Ashford, R.; Desjeux, P.; Deraadt, P. Estimation of population at risk of infection and number of cases of leishmaniasis. Parasitol Today 1992, 8, 104-105. [CrossRef]

151. Kuroyanagi, M.; Murata, M.; Nakane, T.; Shirota, O.; Sekita, S.; Fuchino, H.; Shinwari, Z.K. Leishmanicidal active withanolides from a Pakistani medicinal plant, Withania coagulans. Chem. Pharm. Bull. 2012, 60, 892-897. [CrossRef] [PubMed]

152. Brahmachari, G. Total Synthesis of Bioactive Natural Products; Elsevier: Amsterdam, The Netherlands, 2019. 